\title{
Türkiye'de Seçilen Hava Kalitesi İzleme İstasyonları için Eğilim (Trend) Değerlendirmeleri
}

\section{Eyüp Şişman ${ }^{1 *}$}

${ }^{1}$ Istanbul Medipol Üniversitesi, Mühendislik ve Doğa Bilimleri Fakültesi, Inşaat Mühendisliği Bölümü, Kavacık, 34810, Istabul. ORCID: 0000-0003-3696-9967

\section{Özet}

Mühendislikten ekonomiye, sağlıktan sosyal bilimlere kadar çoğu alanda toplanan çok sayldaki verinin eğilim (gidiş-trend) analizi yöntemleriyle işlenmesi, artan velya azalan durumların ortaya konulmasl, gelecek için öngörüde bulunulması ve sonuçta tüm bu bilgiler ışığında her alanın sorunu ve çözümlerine yönelik yol haritalarının belirlenmesi için yoğun çaba harcanmaktadır. Tüm bu alanlardaki faaliyetlerin sürdürülebilirliği için, en başta çevrenin korunması gerekir. Çalışmada Türkiye'de yakıt olarak ithal ve linyit kömür kullanan termik santrallerin çevresinde yer alan ulusal hava kalitesi izleme istasyonlarında kirletici verilerinin belli periyot içerisindeki değişsimi Yenilikçi Trend (Eğilim) Diyagramı (YTD) yardımıyla değerlendirilmiștir. Yapılan çözümleme ile illerdeki kirlilik eğilimi (trendi) veya sağlık riskindeki değişim ortaya konularak, konuyla ilgilenen idareler, sivil toplum kuruluşları, uzmanlar ve paydaşlar için faydalanabilecekleri grafik, bilgi ve yorumlar üretilmiştir. Havayı kirleten salım (emisyon) verilerinin, belirlenen standartlar arasındaki değişimi, geliştirilen yeni trend analizi yaklaşımındaki görsel grafiklerle açıklanabilirse, hava kalitesine bağlı risk analizlerinin ve önlemlerin daha somut șekilde ortaya konulabilmesi mümkün olacaktır. Yapılan çalıșma sonunda Zonguldak (Merkez), Kahramanmaraş (Merkez), Çanakkale (Merkez, Biga, Çan), Adana (Çatalan, Doğankent, Valilik), Hatay (İskenderun), Manisa (Merkez), Ankara (Sincan), Kütahya ve Şırnak’ın hava kalitesinin zamanla iyileştiği, Kahramanmaraş (Elbistan), Hatay (Antakya), Muğla (Yatağan) ve Manisa (Soma)'nın hava kalitesinin ise zamanla kötüleștiği görülmüștür. Kullanılan verilerin zaman aralığ ve hava kirlilik koşullarında gelinen nokta yapılan araştırma çalışmasına göre değerlendirildiğinde, hava kalitesinde hedefimiz olan iyi koşullara ulaşılabilmesi için daha fazla çaba gösterilmesinin gerektiği anlaşılmaktadır.

\section{Anahtar Sözcükler}

Çevre, Hava Kirliliği, Kömürlü Termik Santraller, Risk Analizi, Trend Analizi, Yenilikçi Trend Diyagramı

\section{Trend Assessments for Selected Air Quality Monitoring Stations in Turkey}

\begin{abstract}
Numerous data collected from engineering, economy, health and social sciences activities are analyzed by trend test methods. After analyzing the data, information about the trend is gathered leading to increasing and / or decreasing trends cases. As a result, intensive efforts are being made to determine the plan for each area's unique problems and solutions in the light of all this information. It is necessary to protect the environment and to ensure that all activities in these areas are sustainable. In this study, the trend in the stations data around the coal-fired power plants is determined by the Innovative Trend Diagram (ITD). With ITD, it is tried to reveal the change in the future air quality trend or health risk. At the end of this analysis, graphics, information and comments are produced for the administrations, non-governmental organizations, experts and stakeholders. If the trend of air pollutant emissions can be explained by the visual graphs, it will be possible to reveal the air quality related risk analyzes and measures in a more concrete way. It has been determined that the air quality of Zonguldak (Center), Kahramanmaraş (Center), Çanakkale (Center, Biga, Çan), Adana (Çatalan, Doğankent, Valilik), Hatay (İskenderun), Manisa (Center), Ankara (Sincan), Kütahya and Şırnak has improved over time. At the same time, Kahramanmaras (Elbistan), Hatay (Antakya), Muğla (Yatağan) and Manisa (Soma) air quality has deteriorated over time. It is clear that further efforts are necessary in order to be able to reach the target conditions of good quality in the air quality.
\end{abstract}

$\underline{\text { Keywords }}$

Environment, Air Pollution, Coal-fired Power Plants, Risk Analysis, Trend Analysis, Innovative Trend Diagram

\section{Giriş}

Gelişmiş ve gelişmekte olan çoğu ülkede elektrik enerjisi talebini karşılayabilmek için özellikle arz güvenliği açısından Tablo 1'de görüldüğü gibi kömürlü termik santrallerin yoğun olarak tercih edildiği bilinmektedir. Artan enerji talebinin karşılanabilmesi için en fazla fosil kaynaklı yakıtlar kullanılmaktadır. Türkiye'nin 2015 y1lı toplam elektrik enerjisi üretimi 261,8 TWh olarak gerçekleşmiştir (URL-1 2018). Bunun 76,166 TWh'lik k1smı kömür ve kömür ürünlerinden üretilmiştir (URL-1 2018). Aynı yıl Amerika'da 1470,997 TWh, Almanya'da 283,710 TWh ve Avusturalya'da 158,610 TWh'lik elektrik enerjisi kömür ve kömür ürünlerinden elde etmiştir (URL-1 2018). 
Almanya'nın sadece kömürden ürettiği elektrik enerjisi Türkiye’nin toplam elektrik enerjisi üretiminden fazladır. Kişi başına gelir seviyesi yüksek diğer bir ülke Avustralya'nın kömüre bağlı elektrik enerjisi üretimi toplam elektrik üretiminin \%62,9'una (URL-1 2018) karş1lık gelmektedir. Dünyada en fazla doğalgaz rezervi bulunan Rusya'nın yine kıyaslama için seçilen 2015 yılında kömürden ürettiği toplam elektrik enerjisi miktarı Türkiye'nin iki katından fazladır. Bu santraller açısından dikkat edilecek en önemli ve kritik husus, çalıştıkları bölgenin çevresel sürdürülebilirliğidir. Ancak genelde bu beklentinin karşılanamadığı, çoğu ülkelerde yatırımlar öncesi hazırlanan fizibilitelerde de tercihin, asgari çevre kriterleri gözetilerek en düşük maliyetli tesisten yana kullanıldığı görülmektedir.

Esasen kurulum aşamasındaki değerlendirmelerin, her türlü çevre tedbiri gözetilerek yapılması gerekir. Pratikte karşılaşılan durum ise genelde tesisler devreye alınıp işletmeye başladıktan sonra, gerek kanunlarda ortaya çıkan değişikliklere ve gerekse uygulamada görülen noksanlıklara göre yenilenirler ve/veya sağlıklı bir çevre için ortaya çıkan tesis yenilenmesi dışındaki yüksek ilave maliyetlere katlanılır. Daha yolun başındayken çevre kriterleri ve sağlık beklentilerine de uygun olarak, yerli kömür rezervlerinin çevre dostu teknolojiler yardımıyla ekonomiye kazandırılması ve beraberinde enerjide dışa bağımlılığımızın azaltılması yönünde her türlü çalışma ülke menfaatlerimiz açısından desteklenmelidir.

Hava kirliliğine sebep olan emisyonlar doğal olaylar ve yaşayabilmemiz için gerekli faaliyetler sonucunda ortaya çıkmakta olup, yüksek değerlerde salındıklarında özellikle çevreyi ve insan sağlığını olumsuz etkilerler. Genelde kükürt dioksit $\left(\mathrm{SO}_{2}\right)$, karbon monoksit $(\mathrm{CO})$, azot oksit $\left(\mathrm{N}_{2} \mathrm{O}, \mathrm{NO}\right)$ benzeri birçok gaz bu yollarla atmosfere salınır. Bunların yanı sıra farklı boyutlarda partikül maddeler de $\left(\mathrm{PM}_{10}, \mathrm{PM}_{2.5}\right)$ atmosfere verilir. Birleşmiş Milletler'e bağlı Dünya Sağlık Örgütü (WHO) sürdürülebilir bir çevre ve insan sağlığını korumak amacıyla, salınan gazlar ve partikül maddeler için birtakım kısıtlamalar getirerek, hava kalitesi standartlarını belirlemiştir. Hava kirliliğinin izlenmesi için, Türkiye'de Çevre ve Şehircilik Bakanlığı (ÇŞB) kontrolünde, ülke genelinde önceden belirlenen noktalarda kurulan istasyonlarda sürekli ölçümler yapılmaktadır. Ulusal Hava Kalitesi İzleme İstasyonları (UHKİ̇) adı verilen bu sistem aracılığı ile ortamda bulunan kirletici miktarları ölçümlenerek, hava kalitesi belirlenmektedir. Hava kalitesinin kötü olmasının ekosistem ve şehir yaşamı üzerindeki olumsuz etkileri, topluma önemli mali yük getirmekle birlikte, hava kalitesini 21.yüzyılın önemli sorunu haline getirmiştir (Timmermans vd. 2015; Telloli vd. 2018). Hava kirletici gazların ve partikül maddelerin insan sağlığına olan pek çok olumsuz etkisi bilinmekte ve bu konudaki araştırmalar devam etmektedir. Hava kirliliğinin solunum ve kardiyovasküler hastalıkları son on yıllarda tetiklediği belirtilmiştir (Anil vd. 2014; Titos vd. 2015). Partikül madde konsantrasyonuna bağlı kirliliğin, özellikle çocukların yer aldığı geniş çapta insan sağlı̆̆ını tehdit ettiği ifade edilmiştir (Burr vd. 2015). Belirtilen sağlıksız koşulların önüne geçilebilmesi için belirlenen hava kalitesi standartlarının izlenmesi çok mühimdir.

Ülkeler bir taraftan hava kalitesini korumaya ve iyileştirmeye çalışırken, diğer taraftan önemli bir sorun olan, artan enerji ihtiyaçlarını ekonomik, güvenlikli ve kesintisiz şekilde karşılayabilmek için de büyük çaba sarf etmektedirler. Enerji ihtiyacını karşılamak için dünya genelinde en çok fosil yakıt kaynaklı santrallerin ön plana çıktığı malumdur. 2015 yılı için kaynak bazında dünyada birincil enerji tüketimine bakılırsa, petrol \%32,9 ile ilk sırada yer alırken, bunu \%29,2 ile kömür ve \%23,9 ile de doğal gazın izlediğini ve toplam olarak yaklaşık \%86 oranında fosil yakıtların kullanıldığı görülecektir (MMO 2017). Bunlar içerisinde de en fazla kömürlü termik santrallerin hava kirliliğine sebep oldukları bilinmektedir. Çevreye olan etkileri bilinmesine rağmen, yerli ve/veya ucuz kaynakların değerlendirilebilmesi, yenilenebilir enerji santralleri ile mukayese edildiklerinde az sayıda büyük enerji üretim kapasitelerine sahip olmaları, kesintisiz üretim sürelerinin cazibesi ve bunlara benzer sıralanabilecek pek çok sebeple kömür yakıtlı termik santrallerin tercih edildiği bilinmektedir. Tablo 1 incelendiğinde Çin, Japonya, Rusya, Almanya, Polonya, Güney Afrika ve Güney Kore gibi çoğu ülkenin faal durumdaki kömürlü termik santrallerinin kişi başına kurulu gücü Türkiye'den fazladır. Kişi başına milli geliri Türkiye'nin çok üzerinde olan Almanya'nın kişi başına düşen kurulu güç kapasitesi de Türkiye'nin yaklaşık 3 katıdır. Uluslararası Enerji Ajansı'nın (IEA) 2040 tahminleri esas alınırsa, birincil enerji arzında kömür, petrol ve doğalgazın payının sırasıyla \%29, \%27 ve \%23 olacağı öngörülmektedir (IEA 2015). 2015 yılında kömüre dayalı santrallerin brüt elektrik üretimi içerisindeki payı ülkemizde yerli kömür olarak \%13,2 ve ithal kömür olarak \%15,3 ile toplam \%28,5 düzeyindedir (TKİ 2016).

WHO hava kirliliğini azaltmanın yolu olarak, özellikle kömüre dayalı enerji üretiminin azaltılmasını tavsiye etmektedir (ÇMO 2017; URL-2 2017). Ancak, gelecek y1llarda Çin, Hindistan ve Güney Afrika gibi bazı yükselen ekonomilerde ve Avustralya, Kanada ve Amerika Birleşik Devletleri gibi bazı gelişmiş ülkelerde kömürün çıkarılması ve kullanımının artması beklenmektedir (Hope 2014). Örneğin, Hindistan'ın kömür tüketiminin 2035'e kadar iki katına çıkması beklenmektedir (Hope 2014). Türkiye'de kömür santralleri için 1990'da 5,5 milyon ton olan kömür ithalatı 2015 'de 34,5 milyon tona çıkmıştır (Algedik 2017). Çok sayıda belge, rapor, makalenin incelenmesi ve değerlendirilmesi sonucunda yakın gelecekte ülkemizde kömür tüketim miktarındaki gidişatın enerji ihtiyacına paralel olarak artacağı tahmin edilmektedir. Sayısal veriler ve kurumların stratejik hedefleri de bu yöndeki eğilimi desteklemektedir. Uluslararası iklim değişikliği müzakerelerinde ise, çevre ile uyumlu faaliyetlere destek verilmesi yönünde tavsiyeler yapılmaktadır. Paris anlaşmasından sonra uluslararası kredi veren kuruluşlar kömür kredilerinden çekilmeye başlamıştır. Sadece 500 MW'dan büyük projelerde (ultra süper) kritik teknoloji yatırımlarına destek verilmesi planlanmış, küçük boyutlu santraller için sıkı tedbirler getirilmiştir (Algedik 2017). 
Tablo 1: Ülkelerin Faal Kömürlü Termik Santral Kurulu Güç Bilgileri

\begin{tabular}{|c|c|c|c|c|}
\hline Ülkeler & $\begin{array}{l}\text { Kişi başına milli } \\
\text { gelir(Dolar) } \\
\text { (IMF 2016) }\end{array}$ & $\begin{array}{l}\text { Kömür Yakıtlı Santral Kurulu } \\
\text { Güç (MW) } \\
\text { (ÇMO 2017, s12) }\end{array}$ & Nüfus (kişi) & $\begin{array}{c}\text { Kişi başına kurulu güç } \\
\text { (KW/kişi) }\end{array}$ \\
\hline Güney Afrika & 5.261 & 40.513 & 52.981 .991 & 765 \\
\hline Tayvan & 22.453 & 17.407 & 23.344 .213 & 746 \\
\hline Polonya & 12.316 & 27.761 & 38.533 .299 & 720 \\
\hline Güney Kore & 27.539 & 33.417 & 50.219 .669 & 665 \\
\hline Çin & 8.113 & 921.227 & 1.414 .548 .510 & 651 \\
\hline Almanya & 41.902 & 53.060 & 82.259 .666 & 645 \\
\hline Sirbistan & 5.376 & 4.294 & 7.241 .295 & 593 \\
\hline Japonya & 38.917 & 44.078 & 126.323 .715 & 349 \\
\hline Rusya & 8.929 & 48.435 & 143.439 .832 & 338 \\
\hline Malezya & 9.360 & 10.008 & 29.784 .600 & 336 \\
\hline Şili & 13.576 & 5.101 & 16.634 .603 & 307 \\
\hline Türkiye & 10.743 & 16.362 & 81.694 .850 & 200 \\
\hline Hindistan & 1.723 & 211.562 & 1.352 .709 .900 & 156 \\
\hline Vietnam & 2.173 & 13.394 & 94.444 .200 & 142 \\
\hline Endonezya & 3.604 & 27.399 & 266.566 .600 & 103 \\
\hline
\end{tabular}

Son yıllarda yeni nesil enerji verimliliği yüksek, temiz kömür teknolojisi olarak adlandırılan ithal kömüre dayalı santraller özel sektör yatırımları ile hızla ülkemizin enerji üretim portföyüne eklenmiş ve eklenmeye devam etmektedir. Verilerdeki eğilime (trend) bakılmadan gerçekleştirilecek planlama, tasarım ve yapılanma ciddi hatalar doğurabilir (Güçlü 2018a). $\mathrm{Bu}$ gelişmeler 1şığında kömürlü termik santrallerin bulunduğu bölge ve yakın çevresine santrallerin kirlilik yönünden yapacağı etkinin net şekilde ortaya konulması ve bölgesel olarak il ve/veya ilçe bazında hava kalitesinin yönetimi, özellikle insan sağlığının korunması açısından zorunludur. Bu amaca yönelik bir adım olarak kömürlü termik santraller çevresindeki hava kalitesinin ve bu kalitedeki değişimin ortaya konulup değerlendirilmesi için bu araştırma çalışması yapılmıştır.

Hava kalitesindeki değişim Mann (1945), Kendall (1975), Sen (1968) ve Haan (1977) tarafindan ortaya konulan modeller ile belirlenebilir. Bunlar içerisinden istatistik prosedüre dayalı Mann-Kendall gidiş testi geçmiş yıllardaki trend analizleri uygulamalarında çok fazla ön plana çıkmaktadır. Bu test ile zaman serisi içerisinde karşılaştırma yapabilmek zordur. Varsayımlara bağlı çözümleme yapması ve seçilen zaman serisi için artış veya azalış şeklinde tek bir sayısal değere bağlı trend bilgisi vermesi incelenen serilerin ayrıntılı çözümlemesini güçleştirmektedir. Yukarıda yer verilen klasik modeller trend analizi araştırmaları için kullanılmıştır (Taylor ve Loftis 1989; Chiew ve McMahon 1993; Hamed ve Rao 1998; Helsel ve Hirsch 2002; Jhajharia vd. 2009; Nalley vd. 2013; Dabanli vd. 2016; Belihu vd. 2017; Güçlü 2018a).

Trend analizi araştırmaları için yakın zamanda, sözel yorumlarında yapılabildiği, Yenilikçi Trend Analizi (YTA) adında, herhangi bir varsayım içermeyen, her türlü zaman serisinde uygulanabilen, oldukça basit bir grafik yaklaşım ortaya konulmuştur (Şen 2012; Şen 2014). Şen yöntemine göre zaman serisi iki eşit alt küme şeklinde düşünülerek, belirlenen 1:1 eğimli bir referans doğrusuna göre veri saçılma dağılımları karşılaştırılarak, trend durumuna karar verilir. $\mathrm{Bu}$ yeni yaklaşımı klasik yöntemlerden ayıran en önemli farklardan biri, trend durumuna göre belli alt kümeler içerisinde ortaya çıkan artan ve azalan gidiş bileşenlerinin ve şiddetinin rahatlıkla ortaya konulabilmesi veya geliştirilmeye açık olmasıdır. Yöntem bilimsel olarak yeni olmasına rağmen, çok sayıda araştırmaya ilham kaynağı olmuştur (Sonali ve Kumar 2013; Markus vd. 2014; Şen 2014; Saplioglu vd. 2014; Dabanli vd. 2016; Cui vd. 2017; Şen 2017; Güçlü vd. 2018 a, Güçlü vd. 2018b; Alashan 2018; Güçlü 2018a; Güçlü 2018b).

$\mathrm{Bu}$ araştırmada hava kalitesinin değişimini belirlemek için kullanılan YTD'da Şen yönteminden esinlenilerek geliştirilmiştir. Yöntem YTA ile ABD Çevre Koruma Ajansı (EPA)'na ait Hava Kalitesi İndeksinin (HKI) bir arada düşünülmesi sonucunda ortaya çıkmıştır. YTD yönteminin hesaplama adımları YTA ile bire bir aynıdır (Güçlü vd. 2018b).

Çalışmanın ana hedefi, dünyada ve ülkemizde hava ve çevre kirliliklerine sebep olmaları sebebiyle sürekli eleştirilen kömür yakıtlı termik santrallere, belli mesafelerde seçilen hava kirliliği ölçüm istasyonlarındaki trend değişimini görebilmek, konuyla ilgili doğru çıkarımlarda bulunabilmek ve çevreyle ilgili tüm paydaşların faydalanabilecekleri bilgi üretiminde bulunabilmektir.

\section{2. Çalışma Alanı}

Türkiye'de hava kalitesi izleme çalışmaları 1982 Anayasası ve 1983 Çevre Kanunu'na kadar dayanmaktadır. Geçen zamanda hava kalitesi düzenlemesiyle ilgili çok sayıda kanun değişikliği, yönetmelik ve genelge yayınlanmıştır. 1982 yılından 2004'e kadar yarı otomatik istasyonlar yardımıla $\mathrm{SO}_{2}$ ve PM10 kirletici parametreleri ölçülmüştür. 
2004 yılında ilk olarak çevrimiçi izlenebilen 8 adet otomatik hava kalitesi ölçüm istasyonu Ankara'da hizmete başlamıştır. Daha sonra 2005 ve 2007 yılları arasında 81 ilde sürekli izlenebilen hava kalitesi ölçüm istasyonları kurulmuştur (URL3 2018). 2005 yılında kurulan UHKİA'na web üzerinden (www.havaizleme.gov.tr) erişim izni vermiştir. Türkiye genelinde bakanlık, belediye ve sanayi tesislerine bağlı bulunan toplam 220 adet sabit ve 3 adet seyyar istasyonun verisine güncel olarak bu adres üzerinden erişim sağlanmıştır (URL-3 2018). ÇŞB’nin 2018 yılında yayınladığı 2017 Çevre Denetim Raporunda hava kalitesindeki belirsizliğin azaltılması ve daha fazla parametrenin ölçülmesi için, istasyon sayısının 330'a çıkartılmasının hedeflendiği belirtilmiştir (ÇŞB 2017). Raporda partikül madde ve kükürt dioksit ölçümlerinin 81 il genelinde 300 noktada yapıldığı belirtilmiştir (ÇŞB 2017). Bu araştırma için seçilen, Türkiye geneli toplam kurulu gücün yaklaşık \%80'ine denk, en büyük kömür yakıtlı termik santraller ve UHKİA'da yer alan hava kalitesi izleme istasyonları Şekil 1'de görülmektedir.

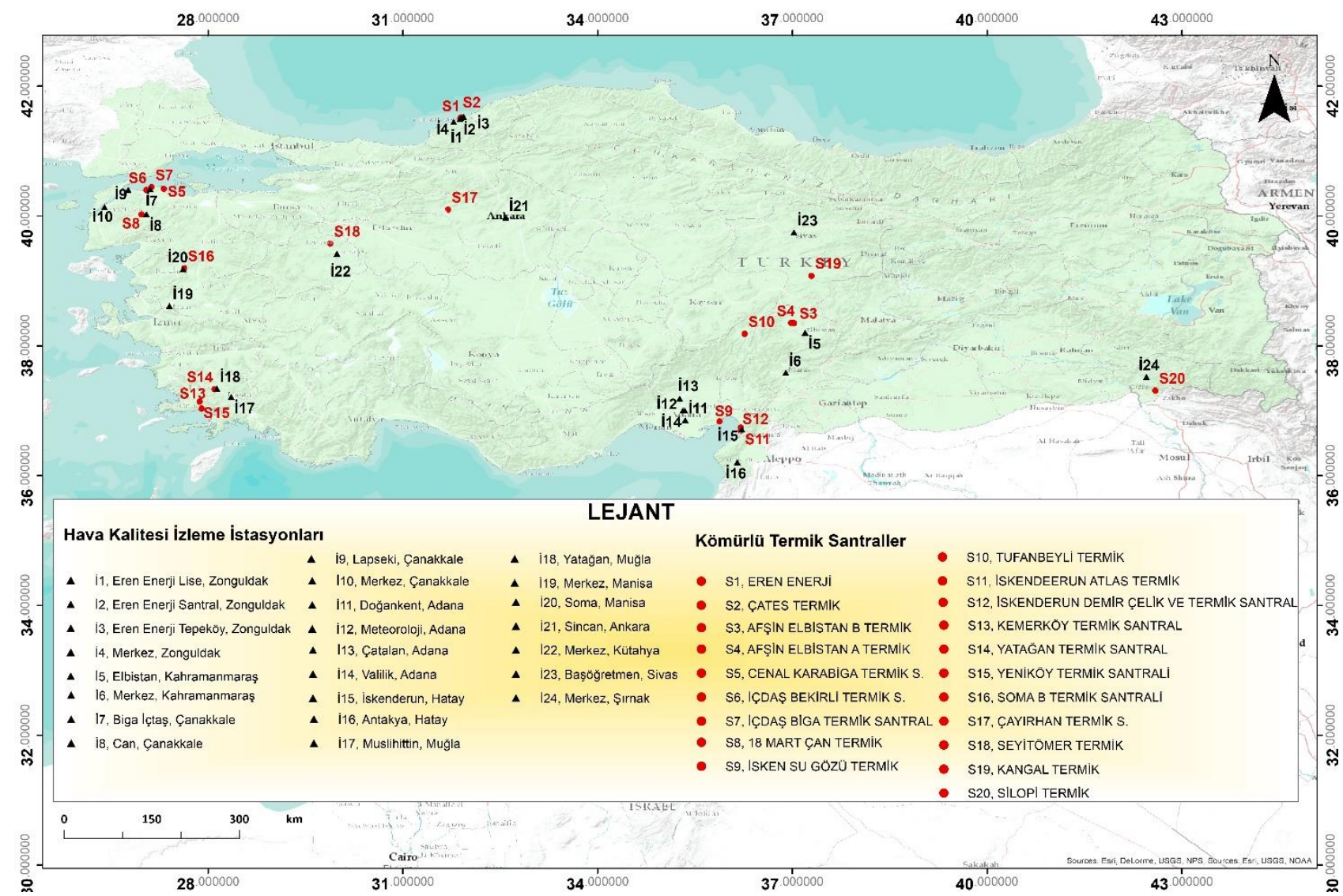

Şekil 1: Hava kalitesi izleme istasyonları genel yerleşim planı

\section{Yöntem}

Şen (2012) yönteminden esinlenilerek ortaya konulan ve ilk dört adımı bu metot ile birebir aynı olan, makaledeki araştırma çalışmasında kullanılan, yöntemin uygulama adımları sırayla maddeler halinde aşağıda verilmiştir.

1. Herhangi bir zaman serisi $\left(\mathrm{x}_{1}, \mathrm{x}_{2}, \ldots, \mathrm{x}_{\mathrm{n}}\right)$ başlangıcından itibaren $\left\{\mathrm{z}_{1, \mathrm{n} / 2}\right\}$ ve $\left\{\mathrm{z}_{2, \mathrm{n} / 2}\right\}$ şeklinde iki eşit parçaya ayrilır.

$\left\{\mathrm{z}_{1, \mathrm{n} / 2}\right\}=\left\{\mathrm{x}_{1}, \mathrm{x}_{2}, \ldots, \mathrm{x}_{\mathrm{n} / 2}\right\}$

ve

$\left\{\mathrm{z}_{2, \mathrm{n} / 2}\right\}=\left\{\mathrm{x}_{\mathrm{n} / 2+1}, \mathrm{x}_{\mathrm{n} / 2+2}, \ldots, \mathrm{x}_{\mathrm{n}}\right\}$

2. Bölünme sonrası elde edilen her bir parçaya ait veri, küçükten büyüğe doğru artan şekilde sıralanır. Bu sıralama sonrası, $\left\{\mathrm{d}_{1}\right\}$ ve $\left\{\mathrm{d}_{2}\right\}$ şeklinde eşit sayıda elemanı olan iki dizi elde edilir.

$\left\{\mathrm{d}_{1}\right\}=\left\{\min \left(\mathrm{z}_{1, \mathrm{n} / 2}\right), \ldots \mathrm{z}_{\mathrm{i}}, \ldots, \max \left(\mathrm{z}_{1, \mathrm{n} / 2}\right)\right\} \quad(1 \leq \mathrm{i} \leq \mathrm{n} / 2)$

$\left\{\mathrm{d}_{2}\right\}=\left\{\min \left(\mathrm{z}_{2, \mathrm{n} / 2)}\right) \ldots \mathrm{z}_{\mathrm{j}}, \ldots, \max \left(\mathrm{z}_{2, \mathrm{n} / 2}\right)\right\} \quad(1 \leq \mathrm{j} \leq \mathrm{n} / 2)$

3. $d_{1}$ dizisinin verilerine karşı, sıralı şekilde düzenlenmiş $d_{2}$ dizisi verileri eşleştirilir. En küçük (en büyük) $d_{1}$ değerine, en küçük (en büyük) $d_{2}$ değeri karşılık gelir. Bu aşamadan sonra, eksenleri aynı ölçekli Kartezyen 
koordinat sisteminde tanımlanan bir grafik üzerinde bu eşleştirilen veriler noktalanarak bir saçılma diyagramı elde edilir.

4. Bu adımda 3.adımda oluşturulan grafik üzerine, tüm veri aralığını kapsayan $1: 1\left(45^{\circ}\right)$ eğime sahip, bir doğru yerleştirilir.

Şen yönteminin bu dört adımı YTD sınamasının iskeletini oluşturmaktadır. Bu dört adımda hazırlanan grafiklerin, Güçlü vd. (2018b) tarafından geliştirilen, Şekil 2'de yer alan şablona göre değerlendirilmesi sonrası her bir verinin eğilimine (trendine) artış ve/veya azalış şeklinde karar verilir. YTD şablonu EPA-AQI hava kalitesi indeks sınıflamasından faydalanılarak oluşturulmuştur. Sağlık endişe koşulları dikkate alınarak tanımlanan, İyi (Yeşil), Orta (Sarı), Hassas (Turuncu), Sağlıksız (Kırmızı), Kötü (Mor) ve Tehlikeli (Kahverengi) sınıflara göre ortaya çıkması muhtemel değişim matrisi 36 farklı alt alanda Şekil 2'de görüldüğü gibi belirlenmiştir. Eğer saçılma noktaları 1:1 doğrusuna yakın 1-1, 2-2, 3-3, 4-4, 5-5, 6-6 matris alanları içerisinde kalıyorsa, sağlık endişe seviyesinde değişim olmadığı için, zaman serisinde kayda değer bir trend olmadığı söylenebilir. Aksi her bir durumda saçılma noktalarının belirlenen alt matris alanlarındaki konumuna göre trendleri Tablo 2'de tanımlanmıştır.

Tablo 2: Yenilikçi trend diyagramına göre hava kalitesi değişim tablosu (Güçlü vd. 2018b)

\begin{tabular}{|c|c|c|c|c|}
\hline Bölge & $\begin{array}{c}\text { Trend } \\
\text { Durumu }\end{array}$ & $\begin{array}{c}\text { 1.Zaman } \\
\text { Aralığı }\end{array}$ & $\begin{array}{c}\text { 2.Zaman } \\
\text { Aralığı }\end{array}$ & Sonuç \\
\hline $1 / 1$ & Trend yok & Yeşil & Yeşil & İyi \\
\hline $1 / 2$ & Artan & Yeşil & Sar1 & Orta \\
\hline $1 / 3$ & Artan & Yeşil & Turuncu & Hassas \\
\hline $1 / 4$ & Artan & Yeşil & Kırmız1 & Sağlıksız \\
\hline $1 / 5$ & Artan & Yeşil & Mor & Kötü \\
\hline $1 / 6$ & Artan & Yeşil & Kahverengi & Tehlikeli \\
\hline $2 / 1$ & Azalan & Sar1 & Yeşil & İyi \\
\hline $2 / 2$ & Trend yok & Sar1 & Sar1 & Orta \\
\hline $2 / 3$ & Artan & Sar1 & Turuncu & Hassas \\
\hline $2 / 4$ & Artan & Sar1 & Kırmız1 & Sağlıksız \\
\hline $2 / 5$ & Artan & Sar1 & Mor & Kötü \\
\hline $2 / 6$ & Artan & Sar1 & Kahverengi & Tehlikeli \\
\hline $3 / 1$ & Azalan & Turuncu & Yeşil & İyi \\
\hline $3 / 2$ & Azalan & Turuncu & Sar1 & Orta \\
\hline $3 / 3$ & Trend yok & Turuncu & Turuncu & Hassas \\
\hline $3 / 4$ & Artan & Turuncu & Kırmız1 & Sağlıksız \\
\hline $3 / 5$ & Artan & Turuncu & Mor & Kötü \\
\hline $3 / 6$ & Artan & Turuncu & Kahverengi & Tehlikeli \\
\hline $4 / 1$ & Azalan & K1rmız1 & Yeşil & İyi \\
\hline $4 / 2$ & Azalan & Kırmız1 & Sar1 & Orta \\
\hline $4 / 3$ & Azalan & Kırmız1 & Turuncu & Hassas \\
\hline $4 / 4$ & Trend yok & Kirmız1 & Kirmız1 & Sağlıksız \\
\hline $4 / 5$ & Artan & Kırmız1 & Mor & Kötü \\
\hline $4 / 6$ & Artan & K1rmız1 & Kahverengi & Tehlikeli \\
\hline $5 / 1$ & Azalan & Mor & Yeşil & İyi \\
\hline $5 / 2$ & Azalan & Mor & Sar1 & Orta \\
\hline $5 / 3$ & Azalan & Mor & Turuncu & Hassas \\
\hline $5 / 4$ & Azalan & Mor & Kırmız1 & Sağlıksız \\
\hline $5 / 5$ & Trend yok & Mor & Mor & Kötü \\
\hline $5 / 6$ & Artan & Mor & Kahverengi & Tehlikeli \\
\hline $6 / 1$ & Azalan & Kahverengi & Yeşil & İyi \\
\hline $6 / 2$ & Azalan & Kahverengi & Sar1 & Orta \\
\hline $6 / 3$ & Azalan & Kahverengi & Turuncu & Hassas \\
\hline $6 / 4$ & Azalan & Kahverengi & Kirmız1 & Sağlıksız \\
\hline $6 / 5$ & Azalan & Kahverengi & Mor & Kötü \\
\hline $6 / 6$ & Trend yok & Kahverengi & Kahverengi & Tehlikeli \\
\hline
\end{tabular}




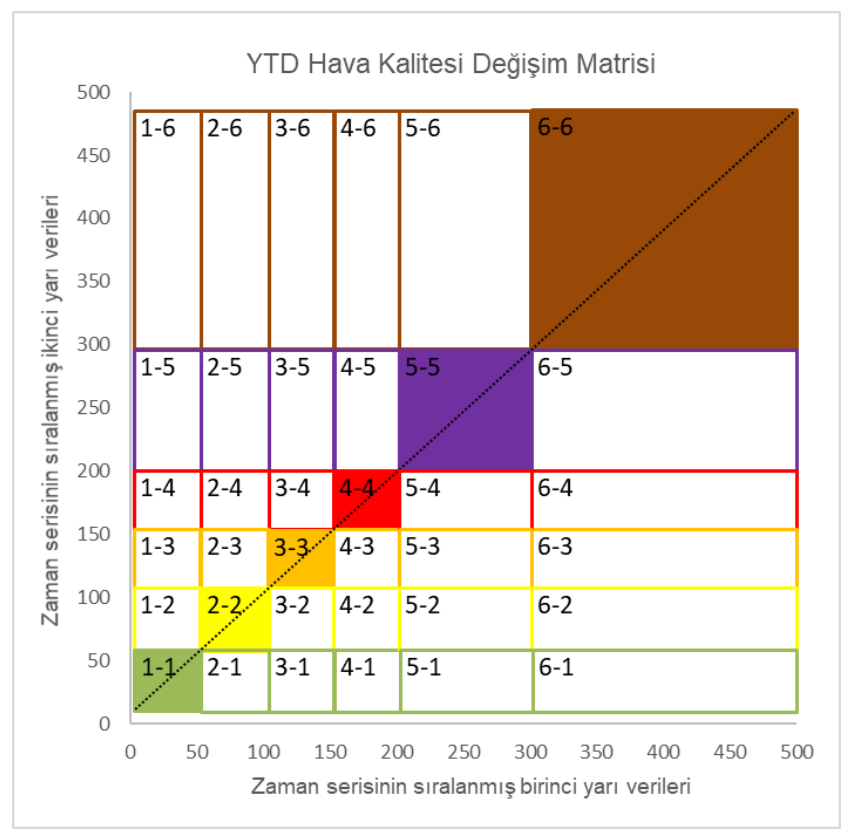

Şekil 2: Yenilikçi trend diyagramına göre hava kalitesi değişim matrisi (Güçlü vd. 2018b)

\section{Uygulama}

Hava kalitesinde trendin belirlenebilmesi için klasik bazı yöntemlerin kullanımı mümkün olmasına rağmen, bu yöntemler ile ayrıntılı sözel yorumlarda bulunulması oldukça zordur. Ayrıca klasik yöntemleri kullanarak EPA'nın AQI sınıflandırmasına göre trend ile ilgili değerlendirmelerde bulunabilmek mümkün değildir. Ancak k1sa süre önce geliştirilen YTD ile hava kalitesi istasyon verilerindeki trendler aşağıda grafiklerde görüldüğ̈ gibi belirlenmiştir. Hava kalitesi sınıflaması için Tablo 3 referans alınmıştır.

Tablo 3: Ulusal hava kalitesi indeksi ve kesme seviyeleri (URL-3 2018)

\begin{tabular}{|c|c|c|c|}
\hline İndeks & \multirow{H}{*}{ HKI } & $\mathbf{S O}_{2}\left[\boldsymbol{\mu g} / \mathbf{m}^{3}\right]$ & $\begin{array}{c}\mathbf{P M 1 0} \\
{\left[\boldsymbol{\mu g} / \mathbf{m}^{3}\right]}\end{array}$ \\
\cline { 3 - 4 } & & $\mathbf{1 ~ S a . ~ O r t . ~}$ & $\mathbf{2 4 ~ S a . ~ O r t . ~}$ \\
\hline İyi & $0-50$ & $0-100$ & $0-50$ \\
\hline Orta & $51-100$ & $101-250$ & $51-100$ \\
\hline Hassas & $101-150$ & $251-500$ & $101-260$ \\
\hline Sağlıksız & $151-200$ & $501-850$ & $261-400$ \\
\hline Kötü & $201-300$ & $851-1100$ & $401-520$ \\
\hline Tehlikeli & $301-500$ & $>1101$ & $>521$ \\
\hline
\end{tabular}
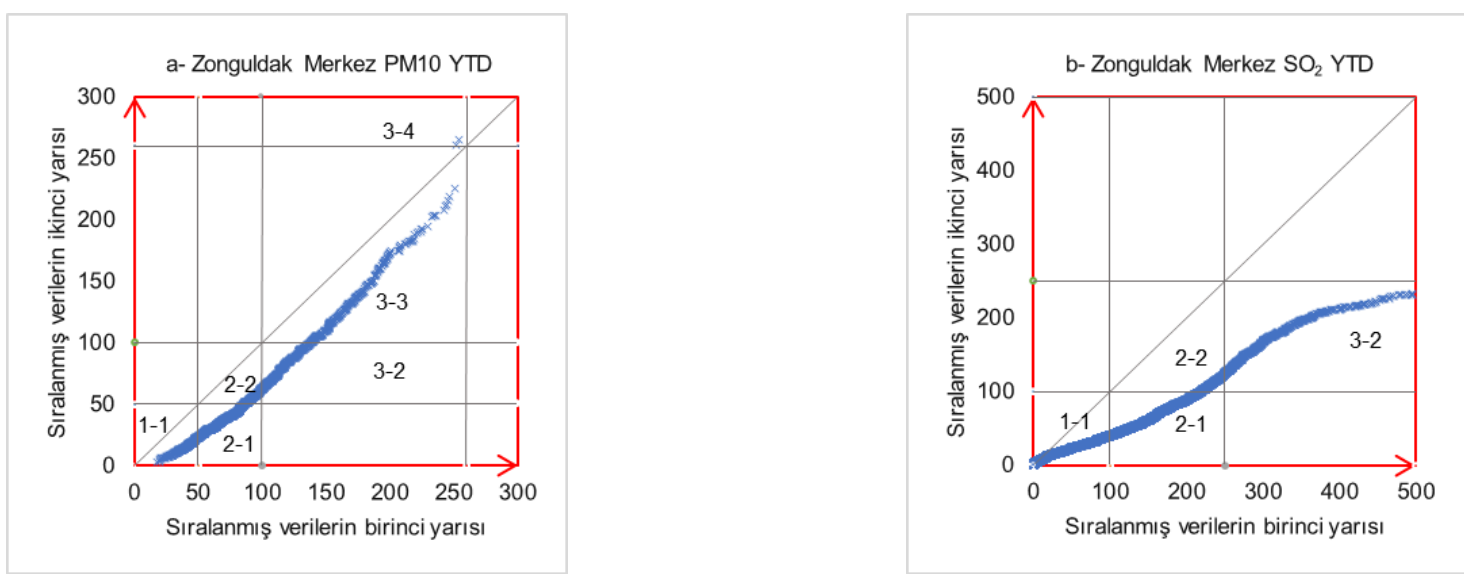

Şekil 3: Zonguldak ili hava kirleticileri yenilikçi trend diyagramları $\left(P M 10, S_{2}\right)$ 

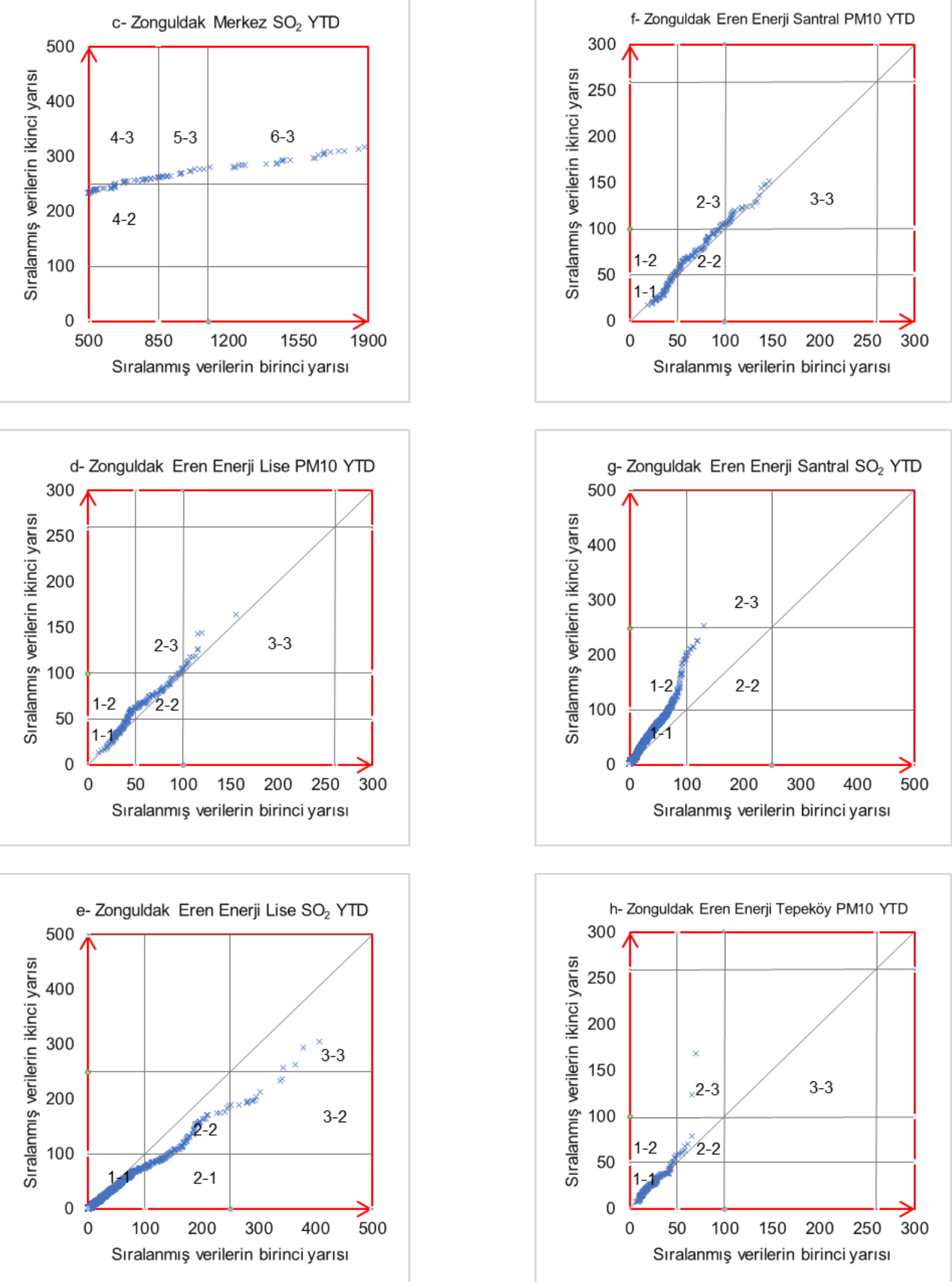

Şekil 3'ün Devamı 


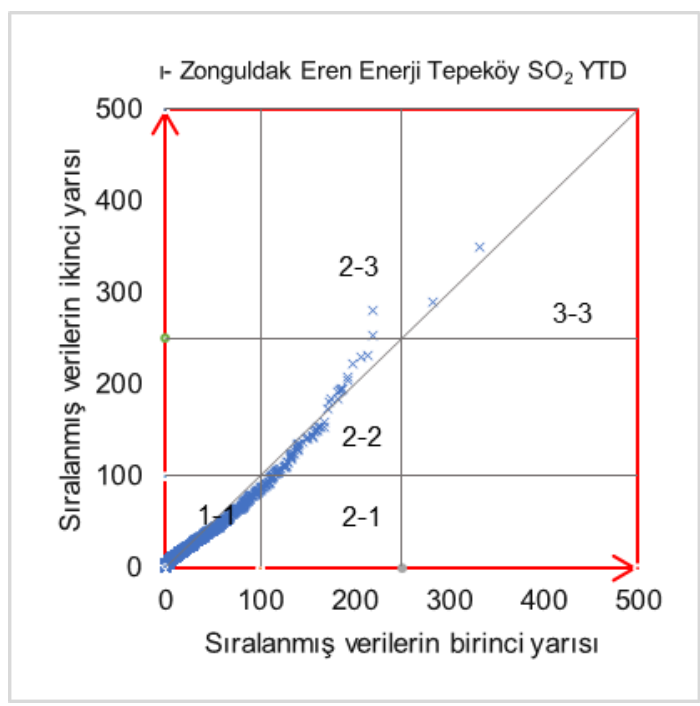

\section{Şekil 3’ün Devamı}

Zonguldak ilinde seçilen dört istasyonda, Merkez, Eren Enerji Lise, Eren Enerji Santral ve Eren Enerji Tepeköy, ölçülen $\mathrm{PM} 10$ ve $\mathrm{SO}_{2}$ hava kirleticileri verilerinin trend analiz sonuçları yukarıda Şekil 3’te görülmektedir. Eren Enerji santral bölgesine yakın 3 istasyonun verileri Aralık 2016 ve Haziran 2018 tarihleri arasına aittir. Merkez istasyonu için analizlerde Nisan 2005 tarihinden Haziran 2018'e kadar olan verilere yer verilmiştir. Zonguldak merkez istasyonuna göre Şekil 3a, b ve c grafiklerinde hava kalitesindeki iyiye doğru eğilim (trend) açıkça görünmektedir. Verilerin YTD'de 1/1, $2 / 2$ ve $3 / 3$ bölgelerine denk düşen saçılım durumlarından, iyi, orta ve hassas koşulların aynı şekilde devam ettiği görülmektedir. $2 / 1$ ve $3 / 2$ bölgelerine denk gelen saçılım durumu ise ortadan iyiye ve hassas bölgeden ortaya doğru bir iyileşmeyi göstermektedir. Bu iyiye gidiş bölgeleri ayrıntılı incelenirse, oldukça fazla günlük iyileşme söz konusudur. Aynı zamanda trendin sözel olarak değişmediği 1/1,2/2 ve 3/3 numaralı bölgelerde, koşul olarak indekse göre değişiklik durumu söz konusu edilmese de sıralanmış verilerin 1:1 $\left(45^{\circ}\right)$ Şen doğrusu (geçiş doğrusu) altında dağılım göstermesi ve doğrudan uzaklığı da her bir indis alt alanında trendin(eğilimin) iyiye doğru olduğunu gösterir. Grafiklerden göründüğü üzere iyi şartların veri sayısının ve dolayısıyla süresinin artması sevindirici iken, orta ve hassas koşullara sahip hava kirlilik değerlerinin iyileştirilmesi için daha fazla çalışılması gerekmektedir. Yakın zamanda ulusal ölçüm ağına dâhil edilen Eren enerji santrali istasyonlarını ait verilerin çözümlemesi sonucu $\mathrm{SO}_{2}$ kirleticisi açısından Lise ve kısmen de Tepeköy santralinde ilk döneme nazaran küçük bir iyileşme söz konusudur. Bu istasyonların sisteme yeni dâhil olması ve verilerdeki eksikler sebebiyle kısıtlı veri üzerinden değerlendirmelerde bulunulabilmiştir. Daha sağlıklı yorumlar için ölçüm dönemi içerisinde kesintisiz veri temin edilmelidir.
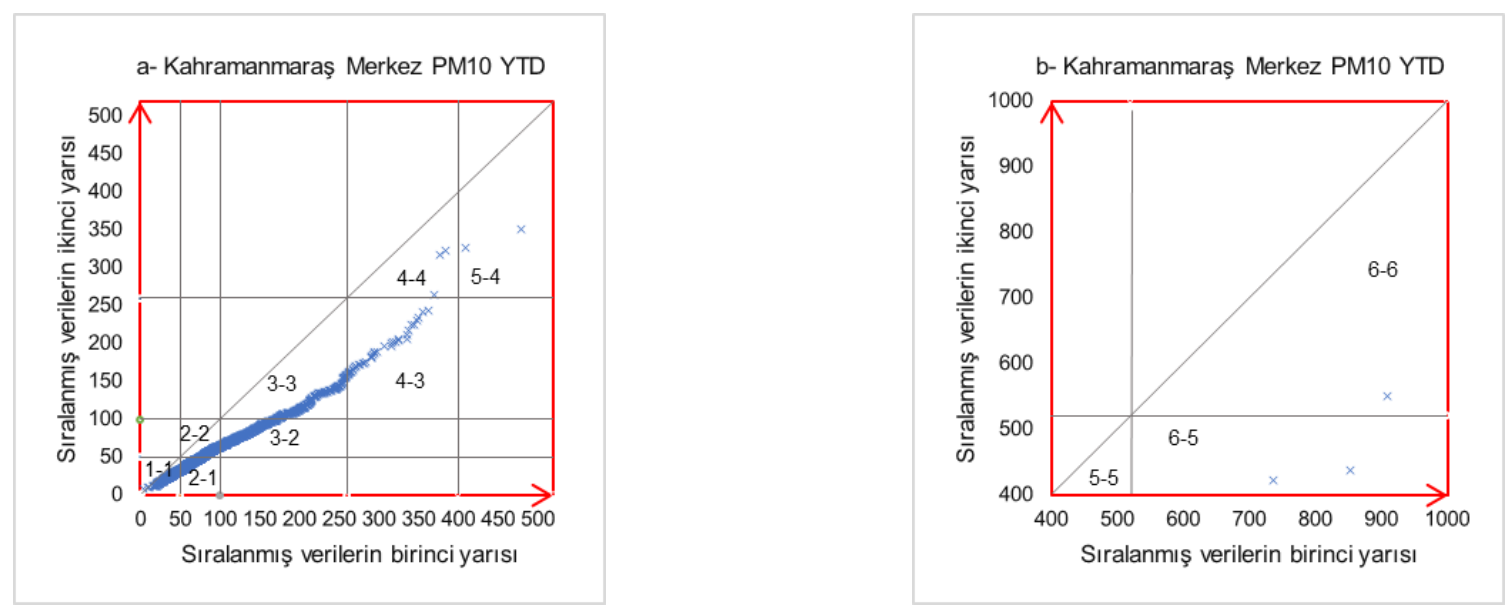

Şekil 4: Kahramanmaraş ili hava kirleticileri yenilikçi trend diyagramları (PM10, $\left.\mathrm{SO}_{2}\right)$ 

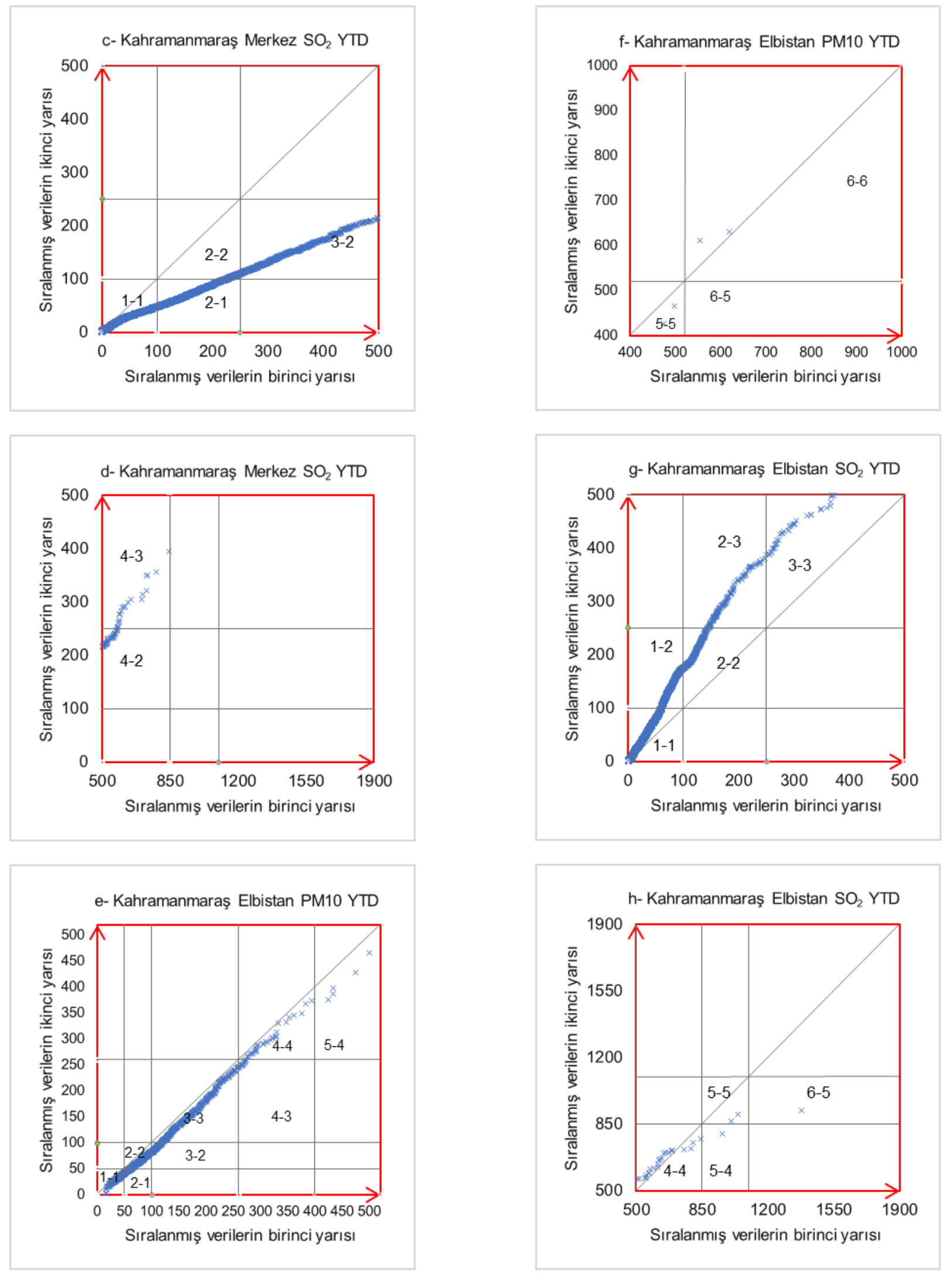

\section{Şekil 4'ün Devamı}

Kahramanmaraş ili hava kirliliği değerlendirmesi için Merkez ve Elbistan istasyonlarında gerçekleştirilen ölçüm verilerinden faydalanılmıştır. 2005 yılından 2018 yılına kadar olan veri toplama döneminde partikül madde ve kükürt dioksit açısından Merkez istasyonu çevresinde kayda değer iyileşmeler Şekil 4a, b, c ve d'de görülmektedir. 
Grafiklerde verilerin 2/1, 3/2, 4/3, 4/2, 5/4, 6/4, 6/5 numaralı alt alan matrisleri ile eşleşmesi hava kalitesindeki iyileşmenin göstergesidir. Elbistan istasyonu için partikül madde YTD grafiği incelendiğinde, Şekil 4e'de görüldüğü gibi, kayda değer bir değişiklik yoktur. İkinci dönem ufak iyileşmelere rağmen (2/1, 3/2, 4/3 ve 5/4), genelde hava kalitesi değerleri, Şekil 4e ve f'den görüldüğü üzere pek değişmemiştir. Veri dağılımının 1:1 doğrusu altında yer alması iyiye doğru trendi açık şekilde göstermektedir. Ancak partikül madde açısından Elbistan çevresinin merkeze göre oldukça kötü durumda olduğu Şekil 4a ile e kıyaslandığında görülmektedir. Ayrıca istasyonlardaki ölçümler sonucu belirlenen belli sıklıklardaki orta, hassas, sağlıksız, kötü ve tehlikeli koşullarda hızlı bir şekilde iyileştirilme süreci takip edilmelidir. Kükürt dioksit açısından Merkez istasyonu çevre şartlarında dikkat çekici iyileşme Şekil 4c ve d'den görülmektedir. Elbistan bölgesinde ise bu gelişmenin tam aksi bir durum yaşandığı Şekil 4g'den görülmektedir.
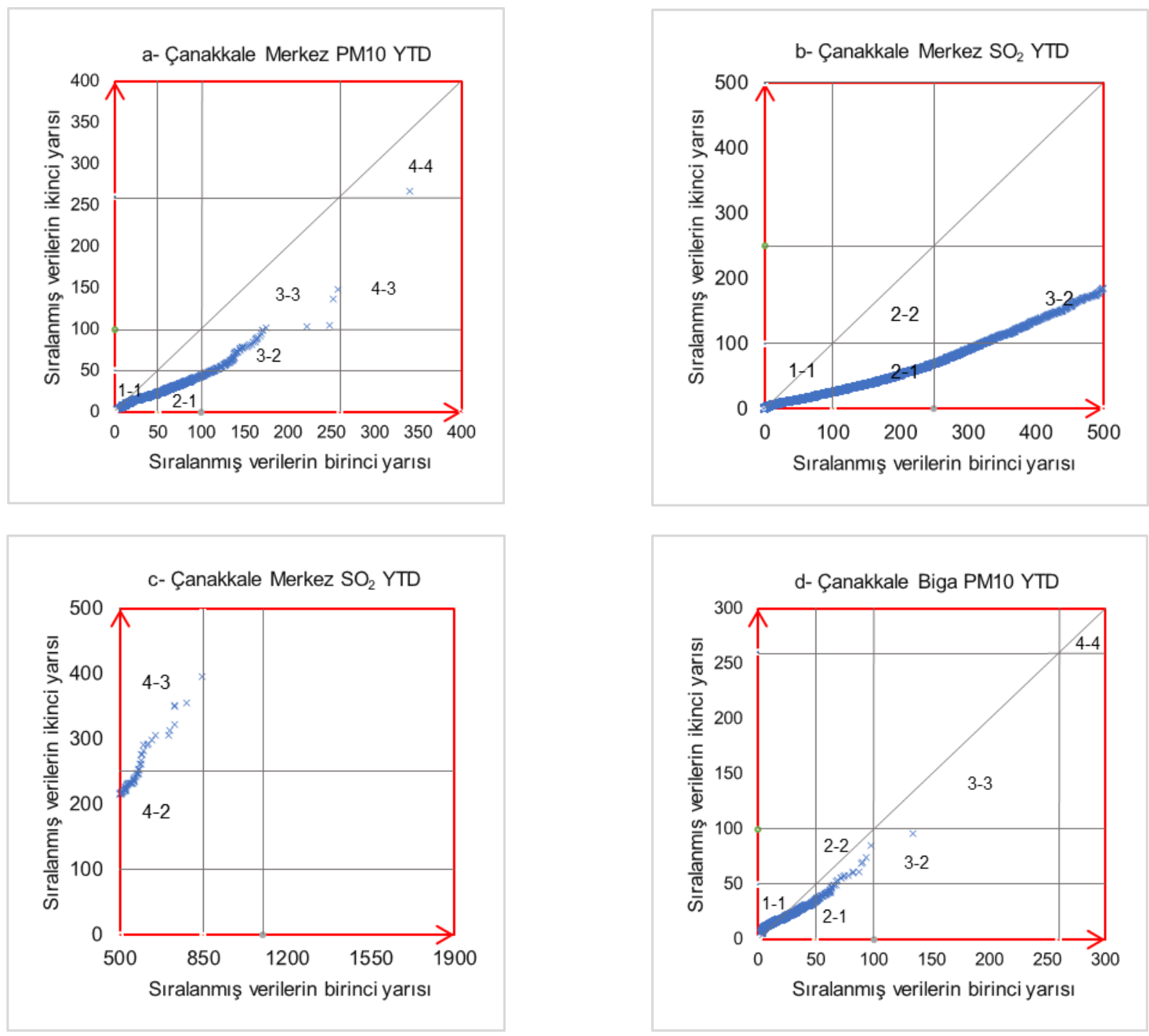

Şekil 5: Çanakkale ili hava kirleticileri yenilikçi trend diyagramları $\left(P M 10, \mathrm{SO}_{2}\right)$

Çanakkale ilinde, Lapseki haricinde, hava kalitesinde bir iyileşme söz konusudur. Grafiklerden Merkez ve Biga istasyonları çevresindeki hava kalitesinde iyileşme daha açı bir şekilde görülmektedir. Lapseki'nin havası diğer bölgelere kıyasla çok daha iyidir. Bu bölgedeki durum önceleri çok iyi koşullara sahip olan havanın, zamanla kirlilik seviyesinin yükselerek orta koşullarda seyretmesidir. Çan istasyonu çevresinde partikül madde açısından, indislere göre iyi ve orta seviyelerde hemen hemen hiç değişiklik olmamıştır. Hassas kirlilik koşullarında, hava kalitesi sınıfında değişiklik olmasına rağmen, verilerin 1:1 doğrusundan alt alanlara doğru uzaklaşması küçükte olsa bir iyileşmenin işaretidir. Çan istasyonuna göre, Şekil 5h ve 1'dan görüldüğü üzere, kükürt dioksit açısından önemli derecede bir iyileşmeden söz edilebilir. 

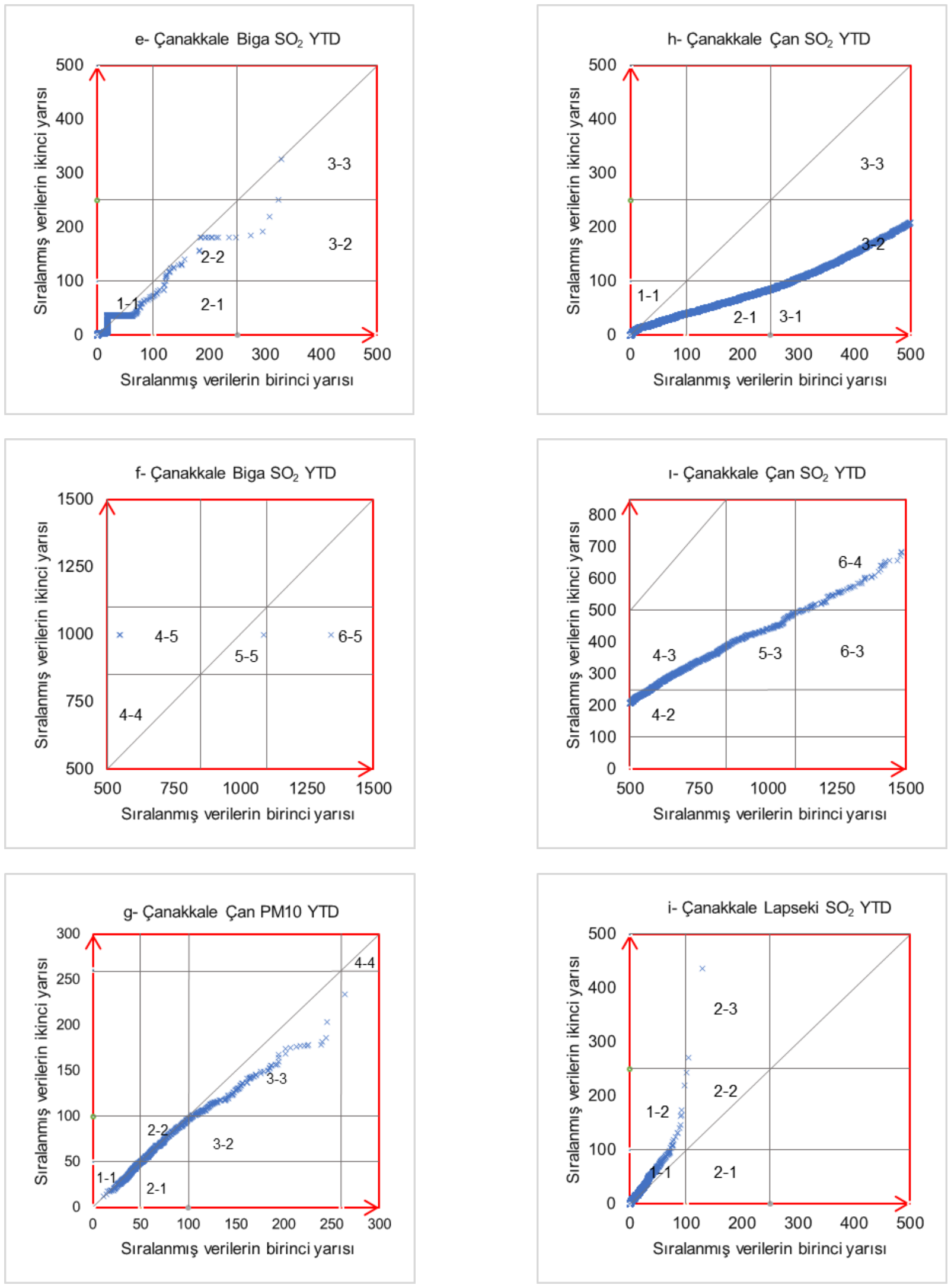

Şekil 5'in Devamı 

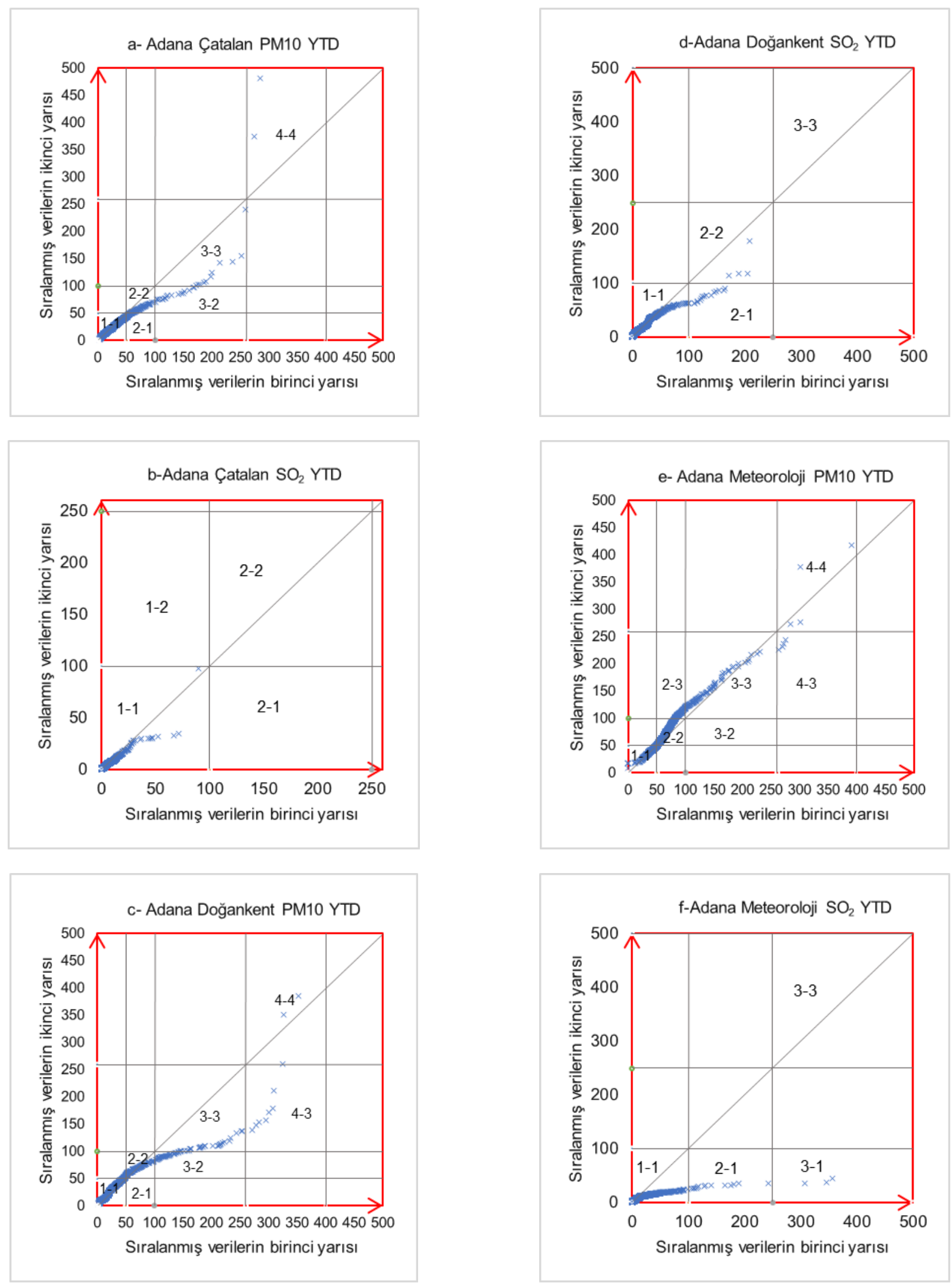

Şekil 6: Adana ili hava kirleticileri yenilikçi trend diyagramları (PM10, $\left.\mathrm{SO}_{2}\right)$ 

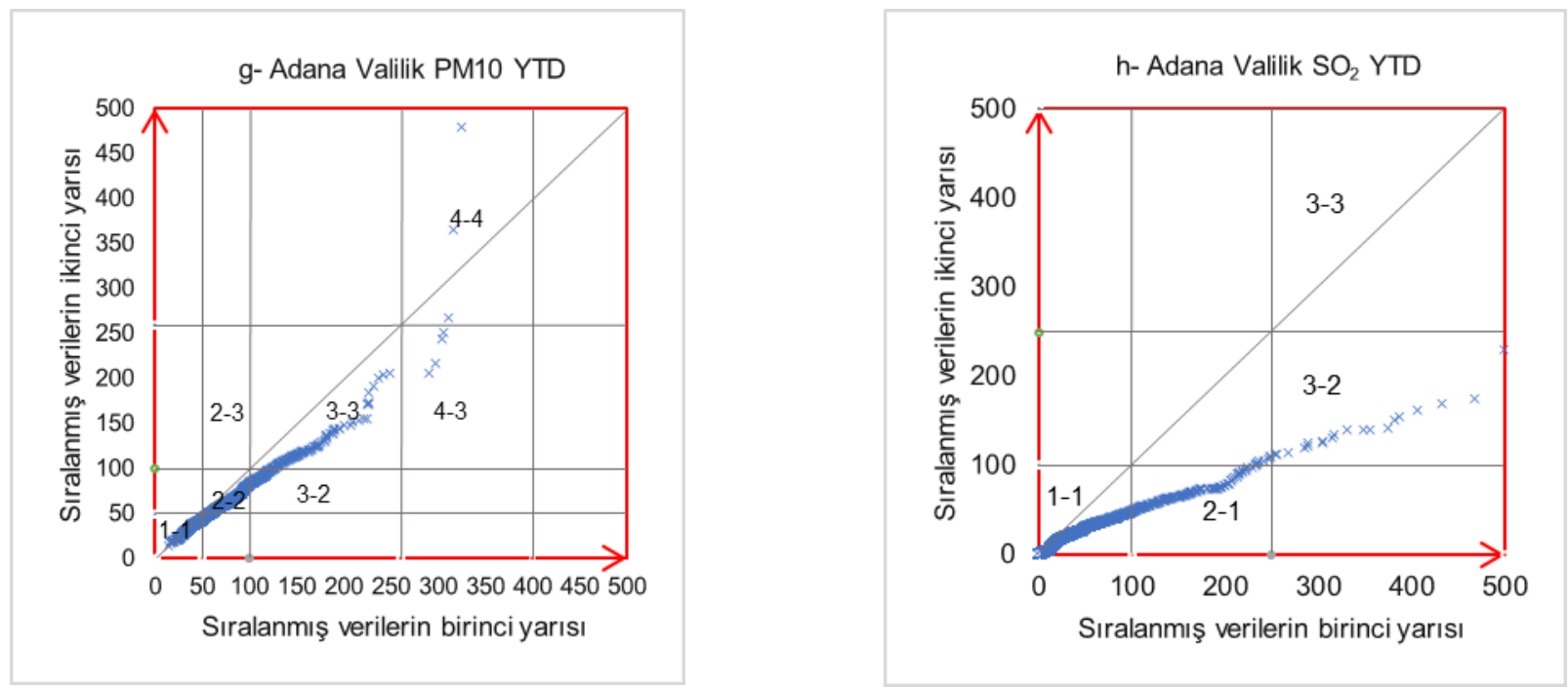

\section{Şekil 6'nın Devamı}

Adana meteoroloji istasyonu çevresinde partikül madde de Şekil 6e'de görüldüğü gibi zamanla küçük bir artış olmuştur. Bu artış indislere göre hava kalitesinde değişim olarak görülmemektedir. Adana bölgesindeki tüm grafiklerden genel olarak bir iyileşme durumunun olduğu sonucu çıkarılabilir. Ancak kurulu istasyonlar santrallere bir hayli uzak mesafededir. Orta ve hassas hava koşullarının sıklıkları fazladır. Nadiren de olsa partikül maddeye göre sağlıksız, kötü ve tehlikeli koşulların olduğu hava kirlilik durumları yaşanmaktadır. Kükürt dioksit açısından da genelde tüm istasyonlara göre, hava kalitesi iyileşmektedir.

Hatay ilinde Antakya ve İskenderun ilçelerinde yapılan hava kalitesi ölçümlerine göre zamanla bir iyileşme olduğu görülmektedir. Kükürt dioksit ve partikül madde miktarları açısından iyi ve orta hava koşullarının görülme sıklığının arttığ grafiklerden görülmektedir. Antakya istasyonu Şekil 7 b'de görüldüğü gibi, kükürt dioksit verilerine göre hava kirliliği artmaktadır. Antakya için partikül madde açısından, Şekil 7a'da görüldüğü gibi, belli bir gidiş söz konusu olmayıp hemen hemen iyi ve orta koşullarda bir değişme yoktur. Hassas ve sağlıksız koşullar açısından küçük bir iyileşme dikkat çekmektedir. Nadir görülen kötü ve tehlikeli koşullar bir basamak iyileşmiştir. Şekil 7c ve d'de görüldüğü gibi İskenderun istasyonunda zamanla ortaya çıkan iyileşme dikkat çekicidir. Sağlıksız koşullardan orta seviyelere bir iyileşme Şekil 7d’de 4-2 alt alanına görüldüğü gibi gerçekleşmiştir.
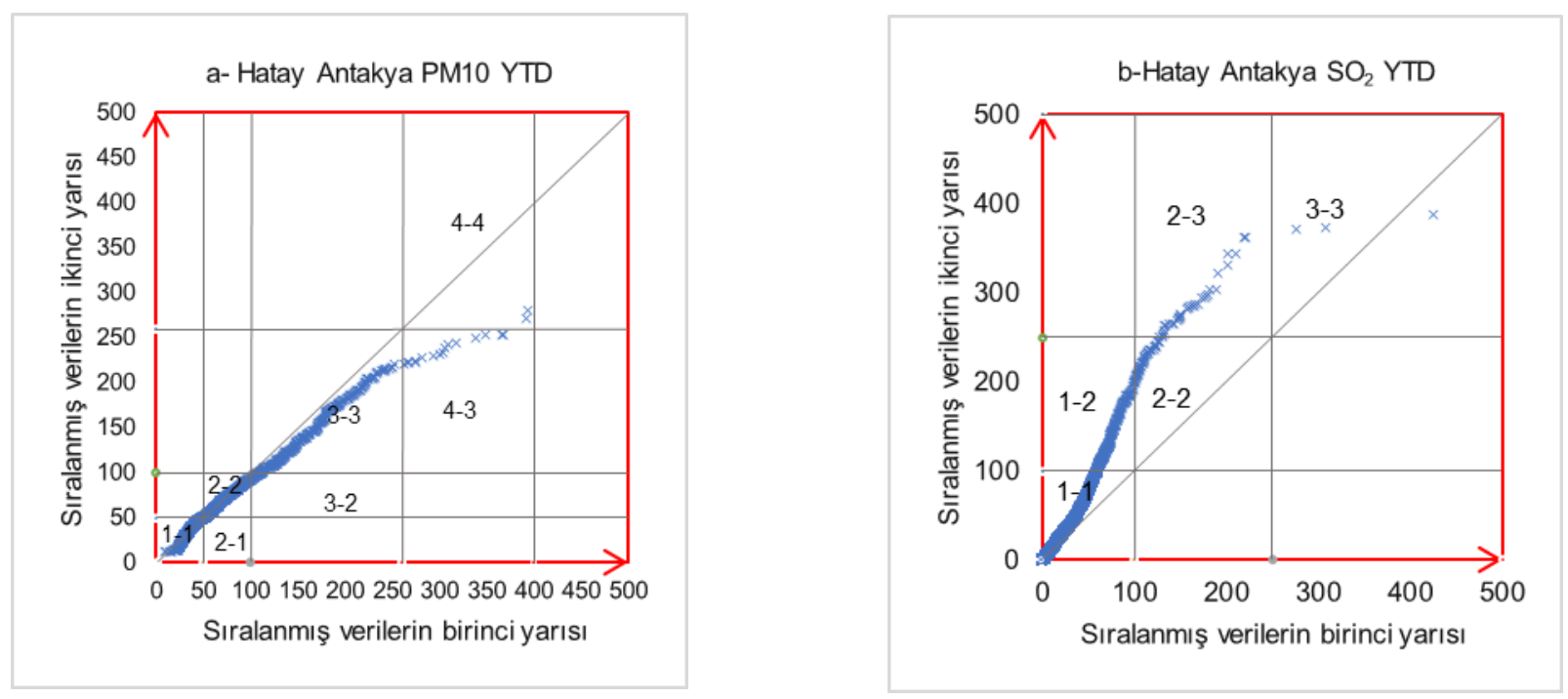

Şekil 7: Hatay ili hava kirleticileri yenilikçi trend diyagramları (PM10, $\left.\mathrm{SO}_{2}\right)$ 

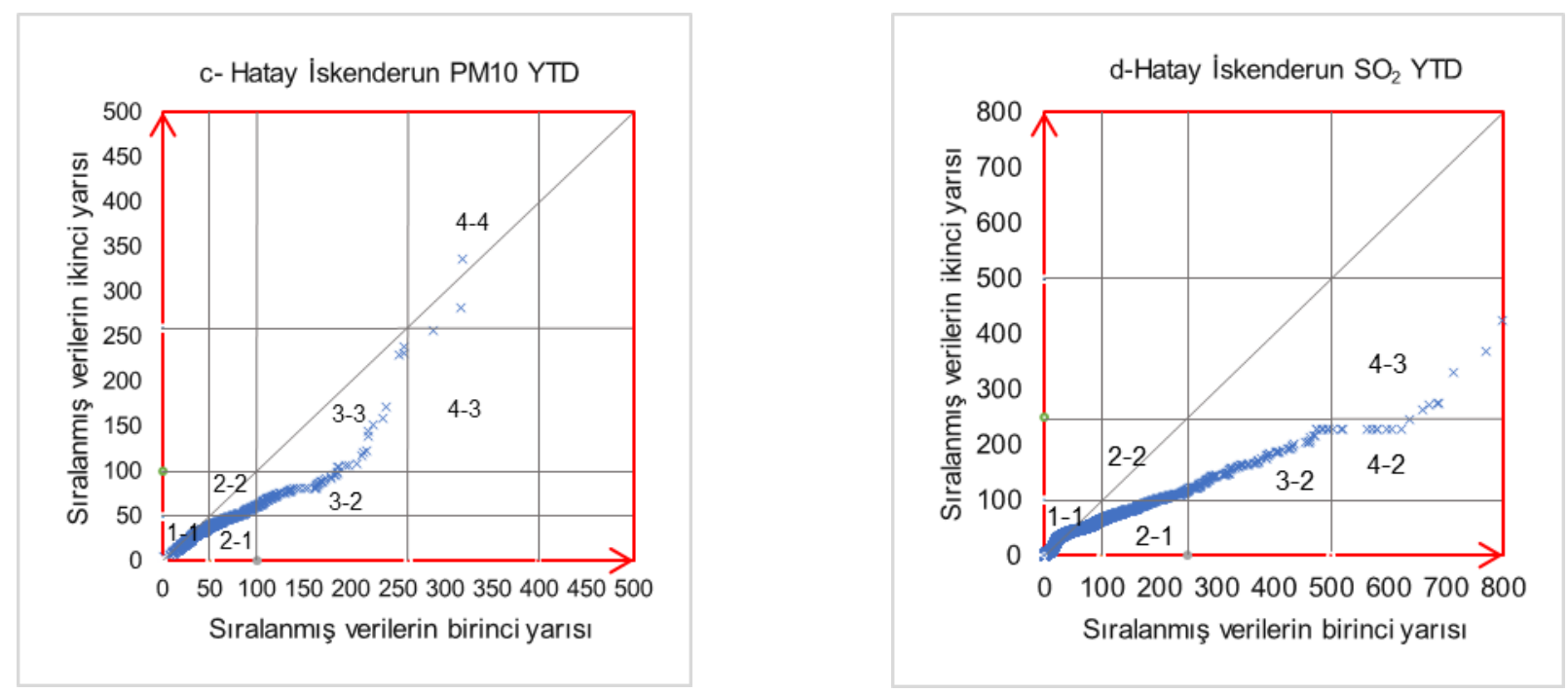

\section{Şekil 7'nin Devamı}

Muğla ilinde seçilen hava kirlilik istasyonlarına göre, hava kalitesindeki gidişatın olumlu yönde değiştiğine yönelik, Şekil 8b ve f grafiklerindeki kükürt dioksit miktarındaki azalma dışında, bir gösterge yoktur. Partikül madde miktarı açısından her iki istasyon ölçüm verileri esas alındığında, Şekil 8a ve d'den görüldüğü gibi zamanla az da olsa kirlilik artmıştır. Hava kalitesi indislerine göre hassas ve orta değerlerin görülme sıklıkları fazladır. Muğla yatağan istasyonu kükürt dioksit ölçüm sonuçlarına göre Şekil 8e ve f'de görüldüğü gibi kirlilik seviyesinde önemli artışlar dikkat çekmektedir. İyi ve orta hava kirlilik seviyelerinden, orta ve hassas seviyelere doğru kirlilik artış1 dikkat çekicidir.
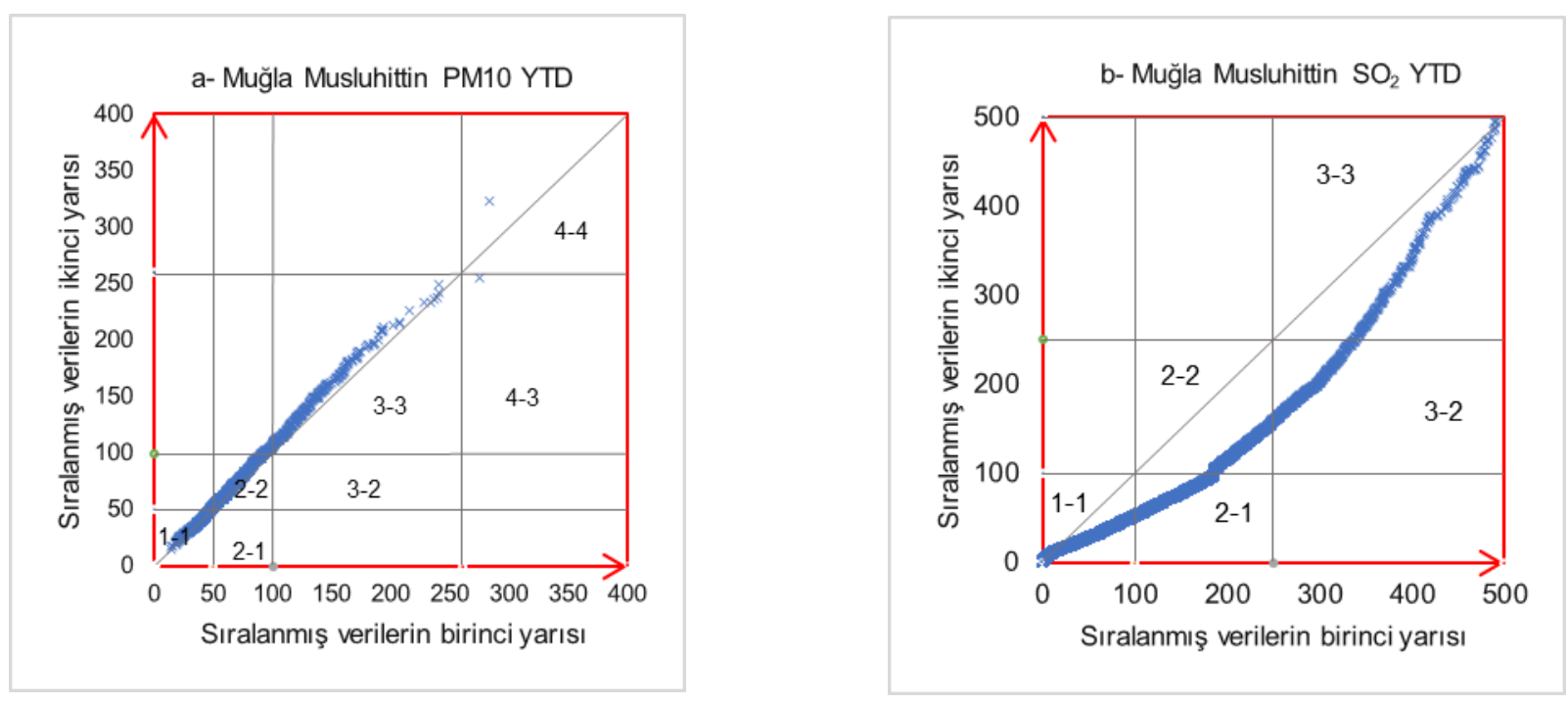

Şekil 8: Muğla ili hava kirleticileri yenilikçi trend diyagramları (PM10, $\left.\mathrm{SO}_{2}\right)$ 

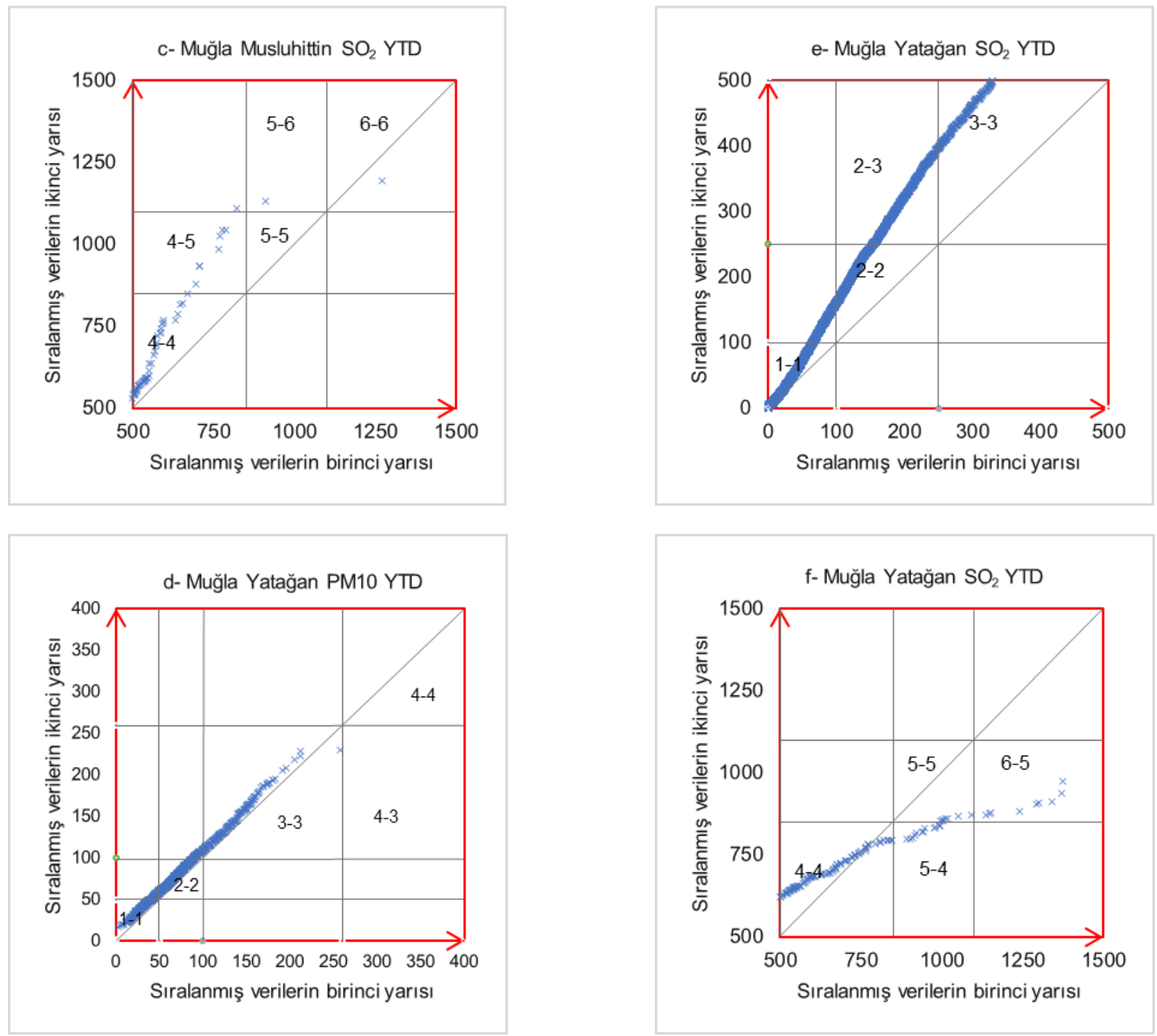

Şekil 8'in Devamı
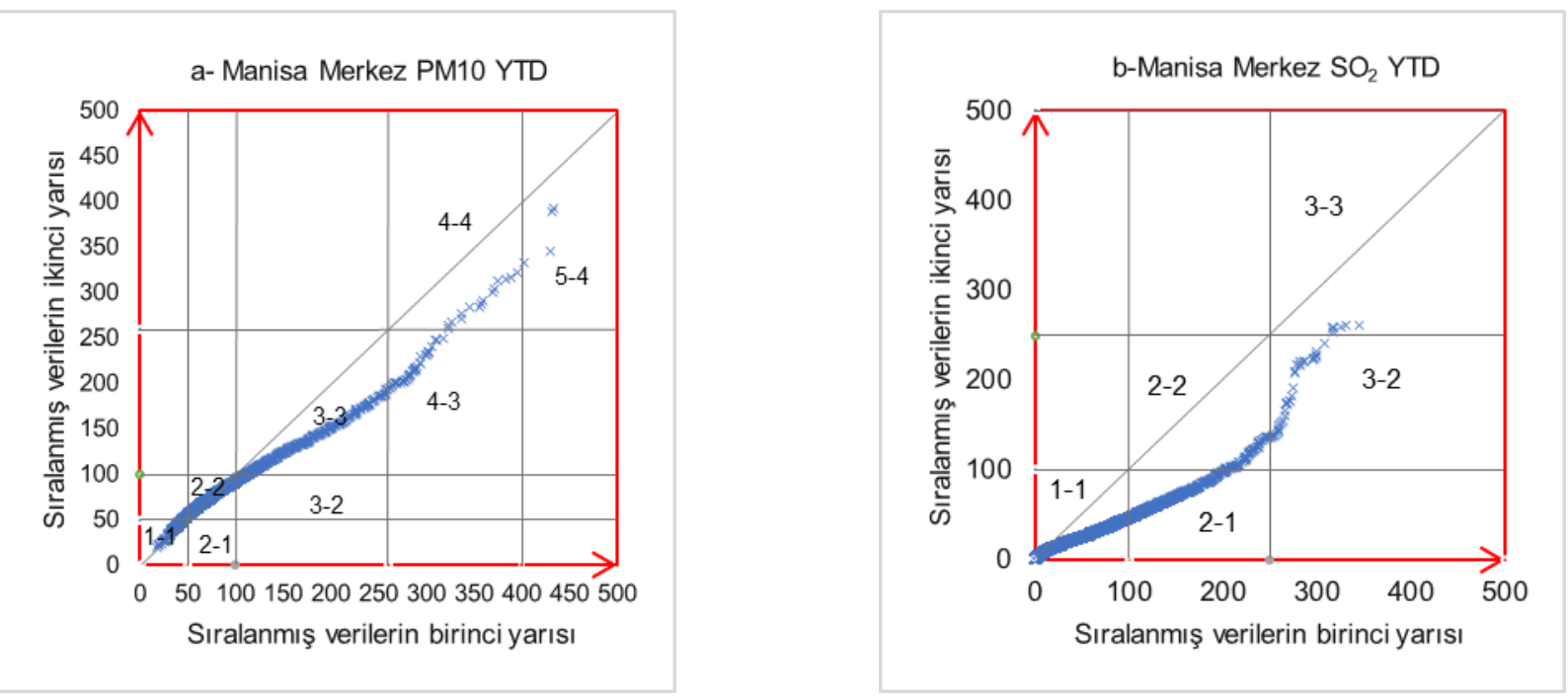

Şekil 9: Manisa ili hava kirleticileri yenilikçi trend diyagramları $\left(\mathrm{PM} 10, \mathrm{SO}_{2}\right)$ 



\section{Şekil 9'un Devamı}

Manisa ilinde seçilen iki istasyona ait elde edilen 5 adet trend grafiği yukarıda Şekil 9'da görülmektedir. Merkez istasyona göre Şekil 9'a ve b'de görüldüğü gibi hava kalitesindeki orta, hassas ve sağlıksız koşullardaki iyileşmeler alt sınıf matrislerinden görülebilir. Partikül madde açısından iyi ve orta indis seviyesine sahip hava kalitesinde değişiklik görülmemektedir. Merkez istasyonun kükürt dioksit kirletici parametresinde Şekil 9b'de görüldüğü gibi orta ve hassas koşullardan iyi ve orta koşullara doğru kayda değer değiş̧im vardır. Soma istasyonuna göre hava kirlilik seviyesindeki artış, özellikle kükürt dioksit açısından Şekil 9d ve e grafiklerinde açıkça görülmektedir. Şekil 9e'de görüldüğü gibi Soma'da kükürt dioksit seviyesinde sağlıksız koşullardan kötü ve tehlikeli seviyelere oldukça hızlı ve yoğun hava kirliliği geçişi söz konusudur. 

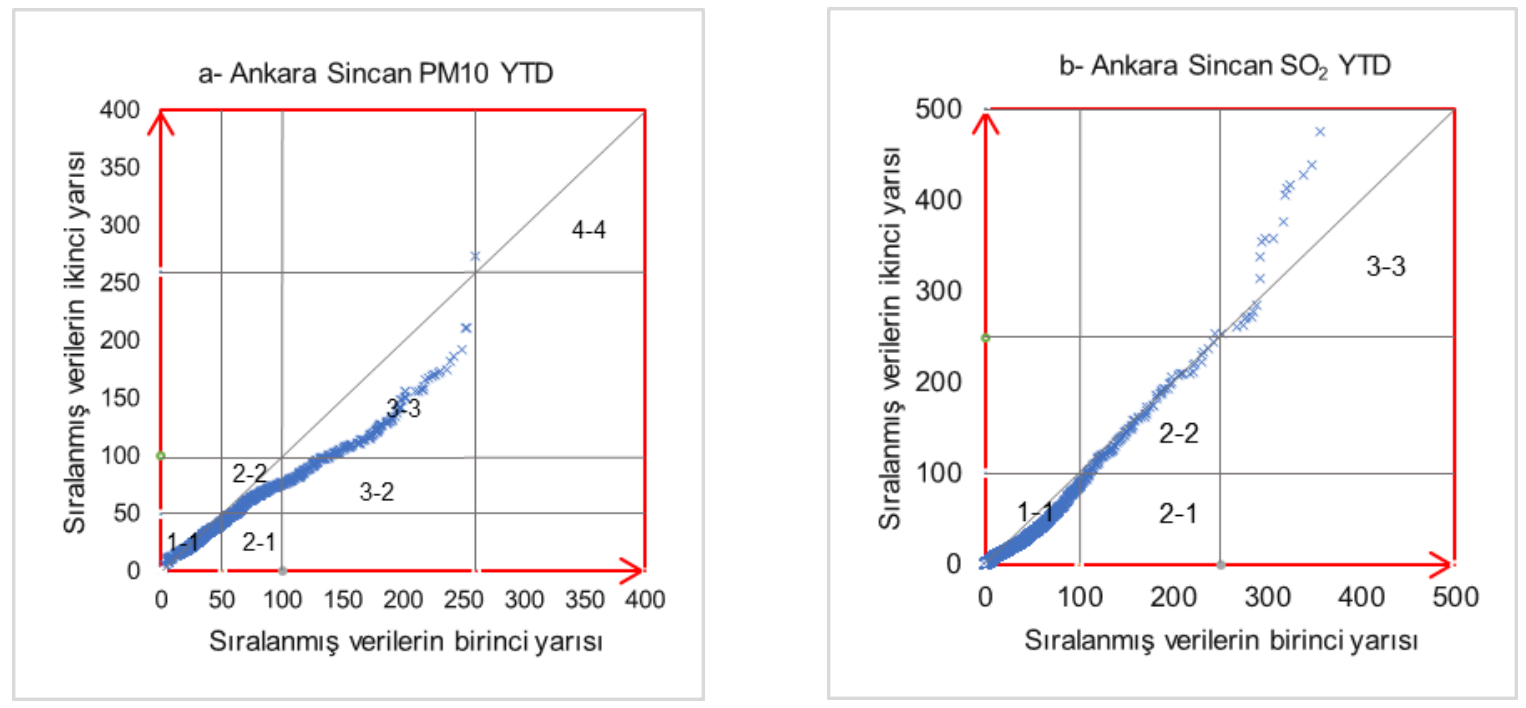

Şekil 10: Ankara ili hava kirleticileri yenilikçi trend diyagramları $\left(P M 10, \mathrm{SO}_{2}\right)$

Sincan istasyonuna göre hava kalitesinde hassastan ortaya doğru küçük bir iyileşme Şekil 10a'da 3-2 numaralı alt bölgede görülmektedir. Grafikler incelendiğinde bölge hava kalitesinin zaman içerisinde daha çok kendini tekrarladığ 1 görülmektedir. Partikül maddenin yarattığı kirlilik açısından Şekil 10a'da görüldüğü gibi bir miktar iyiye gidiş dikkat çekmektedir. Kükürt dioksit açısından hassas şartların nispeten daha kötü olduğu Şekil 10b'de 3-3 alt alanında görülebilir.
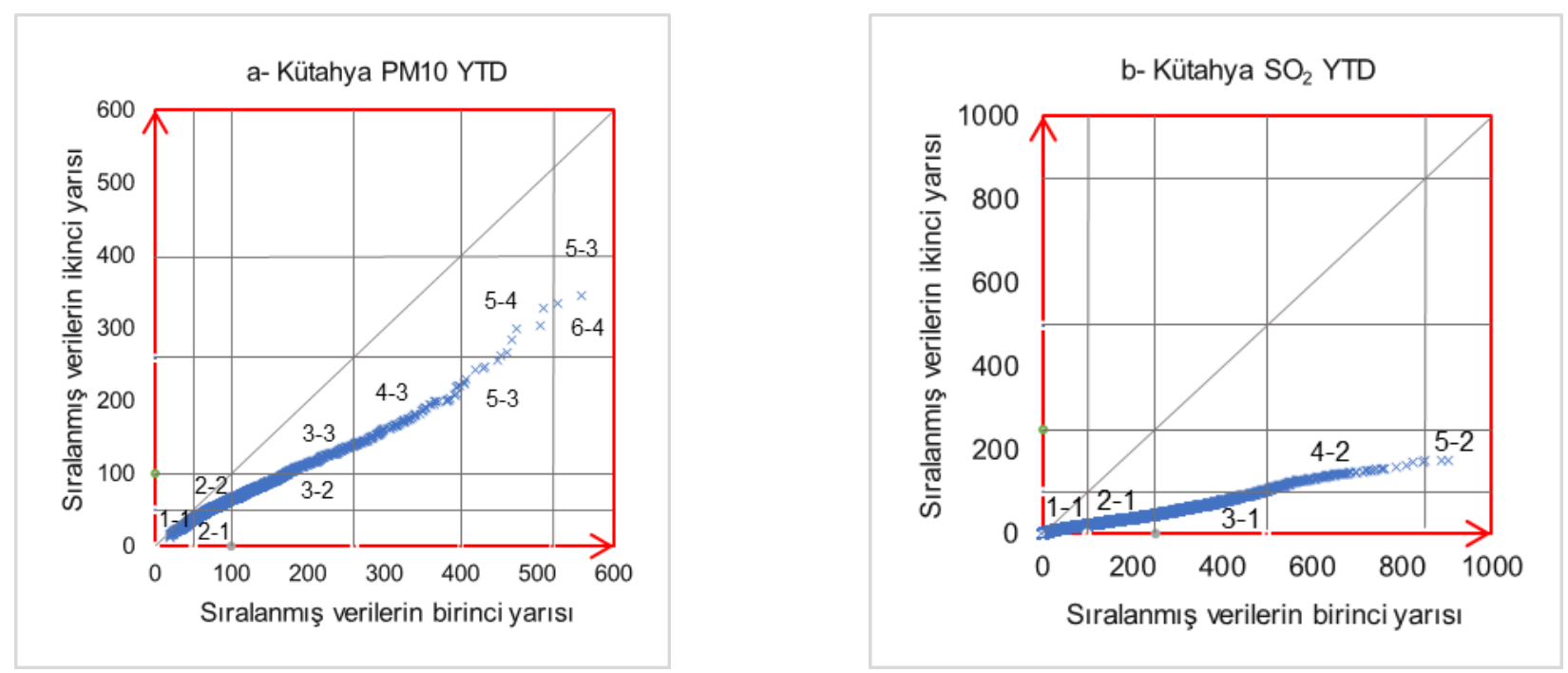

Şekil 11: Kütahya ili hava kirleticileri yenilikçi trend diyagramları $\left(\mathrm{PM10}, \mathrm{SO}_{2}\right)$

Kütahya ilinde hava kirleticilerin YTD ile analizi sonrası, hava kalitesinde genel trendin iyileşme yönünde olduğu anlaşılmaktadır. Hassas ve sağlıksız bölgeden iyi ve orta seviyelere bir eğilim olması istenen bir durumdur. Partikül madde açısından da kükürt dioksite göre daha yavaş olsa da bir trend azalışı olması çok olumlu bir gelişmedir. Partikül madde seviyelerinde kötü ve tehlikeli durumun iyileşmesi sağlık açısından çok olumlu bir gelişmedir.

Şırnak ilinde partikül madde trendinin zamanla Şekil 12'de görüldüğü gibi azalan yönde olduğu belirlenmiştir. Şekilden 2/1, 3/2, 4/3, 5/3 alanlarına verilerin düşmesi hava kirliliğinde bariz bir iyileşmenin göstergesidir. Mevcut eğilim hızı iyi seviyeler için yeterli değildir. 


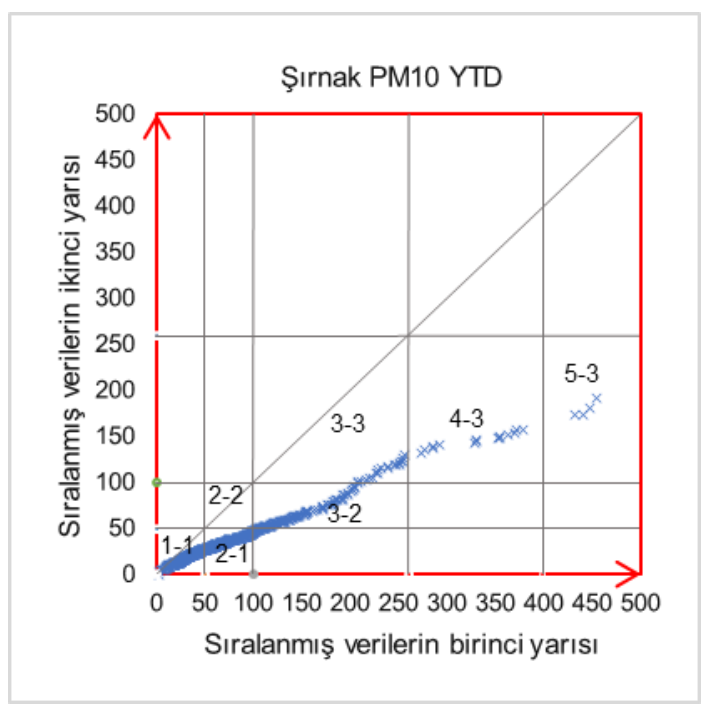

Şekil 12: Şırnak ili hava kirleticileri yenilikçi trend diyagramları (PM10)

\section{Sonuç}

Türkiye'de kirliliğe sebep olduğu ve olacağı gerekçesiyle elektrik enerjisinin kömürden üretimine destek azdır. Bu çalışmasında özellikle kömür yakıtlı termik santrallerin yer aldığı bölgelere yakın hava kirleticilerinin $\left(\mathrm{PM} 10\right.$ ve $\left.\mathrm{SO}_{2}\right)$ zaman içindeki değişimi araştırılmıştır. Kullanılan inceleme yöntemi ve hava kalitesi değerlendirmelerinde uluslararası kriterler dikkate alınmıştır. Genel olarak zaman içerisinde birçok bölgede hava kalitesinin iyileştiği görülmektedir. Hava kirlilik seviyesi değişmeyen ve/ya artan il sayısı daha azdır. Zonguldak (Merkez), Kahramanmaraş (Merkez), Çanakkale (Merkez, Biga, Çan), Adana (Çatalan, Doğankent, Valilik), Hatay (İskenderun), Manisa (Merkez) Ankara (Sincan), Kütahya ve Şırnak'ın hava kalitesi önceki yıllara kıyasla iyileşme eğilimindedir.

Zonguldak (Merkez)'de özellikle kükürt dioksit açısından tehlikeli seviyelerdeki kirlilik hassas noktaya çekilebilmiştir. Kahramanmaraş (Merkez) istasyonuna göre partikül madde açısından sağlıksız koşullar hassas seviyeye indirilmiştir. Çanakkale çevre istasyonlarında ölçülen kirlilik seviyelerinde azalmanın yanı sıra, hava kalitesi tehlikeli boyutlara ulaşan Çan ilçesi çevresinde kükürt dioksit miktarı kayda değer miktarda azalmıştır. Adana'da dört istasyon verisine göre hava kalitesinde ağırlıklı olarak iyi ve orta koşulların sağlandığı görülmektedir. Hassas ve sağlıksız koşullarda da azalmalar vardır. Hatay (İskenderun) bölgesinde sağlıksız ve hassas seviyelerdeki hava kalitesi orta ve iyi koşullara doğru eğilim göstermiştir. Kütahya, Şırnak ve Manisa (Merkez) grafiklerinden bir iki hatta üç kademelik hava kalitesi iyileşmeleri görülebilir. Hava kalitesindeki yukarıda belirtilen bölgelerdeki olumlu gidişin aksine bazı istasyon verilerine göre koşulların kötüleştiği durumlarda ortaya çıkmıştır. Kahramanmaraş (Elbistan), Hatay (Antakya), Muğla (Yatağan) ve Manisa (Soma) incelenen yerleşim bölgeleri arasında ön plana çıkmıştır. Soma'da sağlıksız hava şartları kötü ve tehlikeli şeklinde değişmiştir. Muğla (Yatağan) ve Kahramanmaraş (Elbistan)'da kükürt dioksit açısından iyi, orta ve hassas koşullar birer seviye kötüleşerek orta, hassas ve sağlıksız hava kalitesine dönüşmüştür. Partikül madde açısından değişim olmasa bile grafiklerde görüleceği gibi kirlilik emisyon seviyeleri yüksek seyretmektedir.

Türkiye'de sayısı her geçen gün artan hava kalitesi izleme istasyonları ile tüm yurtta hava kirliliği düzenli bir şekilde izlenmektedir. Araştırma çalışmasından çıkan sonuçlara göre, yapılan izlemelerin hava kalitesinin iyileşmesinde payının olduğu düşünülmektedir. Ayrıca sonuçlardan genelde uygulamada hava kalitesinin yükseltilmesine yönelik gayret ve faaliyetlerin olduğu da anlaşılmaktadır. Ancak diğer taraftan tüm bu bölgelerin hava kalitesinin daha iyi seviyelere getirilebilmesi için çok daha fazla çalışılması gerekmektedir.

\section{Kaynaklar}

Alashan S., (2018), An improved version of innovative trend analyses, Arabian Journal of Geosciences, 11:50, doi:10.1007/s12517018-3393-x.

Algedik Ö., (2017), Kömür ve İklim Değişikliği - 2017, http://panel.stgm.org.tr/vera/app/var/files/k/o/komur-ve-iklim-degisikligi2017.pdf, [Erişim 26 Haziran 2018].

Anil I., Golcuk K., Karaca F., (2014), ATR-FTIR spectroscopic study of functional groups in aerosols, The contribution of a Saharan dust transport to urban atmosphere in Istanbul, Turkey, Water Air and Soil Pollution, 225:1898, doi:10.1007/s11270-014-1898-9.

Belihu M., Abate B., Tekleab S., Bewket W., (2017), Hydro-meteorological trends in the Gidabo catchment of the Rift Valley Lakes Basin of Ethiopia, Physics and Chemistry of the Earth, Parts A/B/C, 104, 84-101.

Burr W.S., Takahara G., Shin H.H., (2015), Bias correction in estimation of public health risk attributable to short-term air pollution exposure, Environmetrics, 26(4), 298-311. 
Chiew F.H.S., McMahon T.A., (1993), Detection of trend or change in annual flow of Australian rivers, International Journal of Climatology, 13, 643-653.

Cui L., Wang L., Lai Z., Tian Q., Liu W., Li J., (2017), Innovative trend analysis of annual and seasonal air temperature and rainfall in the Yangtze River Basin of China during 1960-2015, Journal of Atmospheric and Solar-Terrestrial Physics, 164, 48-59.

ÇMO, (2018), Hava Kirliliği Raporu 2017, TMMOB Çevre Mühendisleri Odas1, http://cmo.org.tr/resimler/ekler/2145efce8f89f52 _ek.pdf, [Erişim 01 Temmuz 2007].

ÇŞB, (2018), 2017 Çevre Denetimi Raporu, T.C. Çevre ve Şehircilik Bakanlığı, http://webdosya.csb.gov.tr/db/ced/icerikler/2017_ cevre_denet-m_raporu-20180404102311.pdf, [Erişim 10 Temmuz 2018].

Dabanlı İ., Şen Z., Yeleğen M.Ö., Şişman E., Selek B., Güçlü Y.S., (2016), Trend assessment by the innovative-Şen method, Water Resour Manag, 30(14), 5193-5203.

Güçlü Y.S., (2018a), Alternative trend analysis: half time series methodology, Water Resources Management, 32(7), 2489-2504.

Güçlü Y.S., (2018b), Kıyaslamalı yenilikçi eğilim çözümlemesi temelleri ve uygulamaları, Doğal Afetler ve Çevre Dergisi, 4(2), $182-$ 191.

Güçlü Y.S., Şişman E., Yeleğen M.Ö., (2018a), Climate change and frequency-intensity-duration (FID) curves for Florya station, Istanbul, Journal of Flood Risk Management, doi: 10.1111/jfr3.12229.

Güçlü Y.S., Dabanli İ., Şişman E., Sen Z., (2018b), Air quality (AQ) identification by innovative trend diagram and AQ index combinations in Istanbul megacity, Atmospheric Pollution Research, doi:10.1016/j.apr.2018.06.011.

Haan C.T., (1977), Statistical methods in hydrology, The Iowa State University Press, Ames, Iowa, 378ss.

Hamed K.H., Rao A.R., (1998), A modified Mann-Kendall trend test for autocorrelated data, Journal of Hydrology, 204, $182-196$.

Helsel D.R., Hirsch R.M., (2002), Statistical methods in water resources, Techniques of water resources investigations, Book 4, Chapter A3, U.S. Geological Survey, Shenandoah, TX.

Hope M., (2014), The future of coal in China, India, Australia, the US, EU and UK, The Carbon Brief, http://www. carbonbrief.org/blog/2014/07/the-future-of-coal-in-china-india- the-us-eu-and-uk, [Erişim 21 Haziran 2015].

IEA, (2015), World Energy Outlook 2015, International Energy Agency, https://www.iea.org/Textbase/npsum/WEO2015SUM.pdf, [Erişim 15 Temmuz 2018].

Jhajharia D., Shrivastava S.K., Sarkar D., Sarkar S., (2009), Temporal characteristics of pan evaporation trends under the humid conditions of northeast India, Agricultural and Forest Meteorology, 149, 763-770.

Kendall M.G., (1975), Rank correlation method, 4th Edition, Charless Griffin, London, 202ss.

Mann H.B., (1945), Nonparametric tests against trend, Econometrica, 13, $245-259$.

Markus M., Demissie M., Short M., Verma S., Cooke R., (2014), Sensitivity analysis of annual nitrate loads and the corresponding trends in the Lower Illinois River, Journal of Hydrologic Engineering, 19(3), 533-543.

MMO, (2017), Türkiye'de termik santraller 2017, Yayın No: MMO/668, TMMOB Makine Mühendisleri Odas1, Ankara, 158ss.

Nalley D., Adamowski J., Khalil B., Ozga-Zielinski B., (2013), Trend detection in surface air temperature in Ontario and Quebec, Canada during 1967-2006 using the discrete wavelet transform, Atmospheric Research, 132-133, 375-398.

Saplioglu K., Kilit M., Yavuz B.K., (2014), Trend analysis of streams in the western mediterranean basin of Turkey, Fresenius Environmental Bulletin, 23(1A), 313-324.

Sen P.K., (1968), Estimates of the regression coefficient based on Kendall's tau, Journal of American Statistical Association, 63(324), 1379-1389.

Sonali P., Kumar Nagesh D., (2013), Review of trend detection methods and their application to detect temperature changes in India, Journal of Hydrology, 476, 212-227.

Şen Z., (2012), Innovative trend analysis methodology, Journal of Hydrologic Engineering, 17(9), 1042-1046.

Şen Z., (2014), Trend identification simulation and application, Journal of Hydrologic Engineering, 19(3), 635-642.

Şen Z., (2017), Innovative trend methodologies in science and engineering, Springer, Heidelberg, Germany, 349ss.

Taylor C.H., Loftis J.C., (1989), Testing for trend in lake and groundwater quality time series, Water Resources Bulletin 25(4), 715 726.

Telloli C., Chicca M., Pepi S., Vaccaro C., (2018), Saharan dust particles in snow samples of Alps and Apennines during an exceptional event of transboundary air pollution, Environmental Monitoring and Assessment, 190(1), doi:10.1007/s10661-017-6412-6.

Timmermans R.M.A., Lahoz W.A., Attié J.L., Peuch V.H., Curier R.L., Edwards D.P., Builtjes P.J.H., (2015), Observing system simulation experiments for air quality, Atmospheric Environment, 115, 199-213.

Titos G., Lyamani H., Drinovec L., Olmo F.J., Močnik G., Alados-Arboledas L., (2015), Evaluation of the impact of transportation changes on air quality, Atmospheric Environment, 114, 19-31.

TKİ, (2016), 2015 Kömür (Linyit) Sektör Raporu, Türkiye Kömür İșletmeleri Kurumu, http://www.enerji.gov.tr/File/?path=ROOT \%2F1\%2FDocuments\%2FSekt\%C3\%B6r\%20Raporu\%2FSEKT\%C3\%96R\%20RAPORU\%202015\%2030.06.2015\%20SON.pd f, [Erişim 15 Haziran 2018].

URL-1, (2018), Coal fired power plant, https://energyeducation.ca/encyclopedia/Coal_fired_power_plant\#cite_note-2, [Erişim 17 Eylül 2018].

URL-2, (2017), World Health Organization, Ambient (outdoor) air quality and health, http://www.who.int/mediacentre/factsheets/ fs313/en/, [Erişim 11 Temmuz 2018].

URL-3, (2018), Hava Kalitesi İzleme İstasyonları Web Sitesi, http://www.havaizleme.gov.tr/Default.ltr.aspx, [Erişim 25 Haziran 2018]. 